https://doi.org/10.18778/7525-969-8.09

\title{
Dariusz Wybranowski
}

\section{Armia Republiki Serbskiej w Bośni (1992-1995) - geneza, struktura i pierwsze lata istnienia}

\author{
Proces tworzenia się serbskich formacji zbrojnych i Armii Republiki \\ Serbskiej na tle kształtowania się granic Republiki Serbskiej w BiH \\ (1991-1993)
}

W latach 1990-1991 rozpoczą się proces dezintegracji politycznej Socjalistycznej Federacyjnej Republiki Jugosławii (SFRJ) ${ }^{1}$. Swój dotychczasowy monopol władzy Związek Komunistów Jugosławii utracił na rzecz powstajacych w poszczególnych republikach związkowych partii o profilu narodowym, z których część, tak jak w Słowenii i w Chorwacji, zaczęła dążý do niezależności. Deklaracje niepodległości obu republik z czerwca $1991 \mathrm{r}$. wywołały sprzeciw rządu w Belgradzie i wybuch zbrojnego konfliktu². O ile rząd federalny musiał

${ }^{1}$ Por. więcej m.in. M. Waldenberg, Rozbicie Jugostawii od separacji Stowenii do wojny kosowskiej, Warszawa 2003, s. 64 i n.; J. Wojnicki, Przeobrażenia ustrojowe państw postjugosłowiańskich (1990-2003), Pułtusk 2003, s. 26 i n.; M.J. Zacharias, Komunizm, federacja, nacjonalizmy. System władzy w Jugosławii 1943-1991. Powstanie, przekształcenia, rozkład, Warszawa 2004, s. 478 i n.; S.L. Szczesio, Droga ku wojnie - sytuacja w Bośni $i$ Hercegowinie w latach 1990-1992, [w:] Batkany w XX $i$ XXI wieku. Historia - polityka - kultura. Materiaty z konferencji „Poznać Bałkany”. Toruń, 29 maja 2009 roku, pod red. H. Stysa i Sz. Sochackiego, Toruń 2009, s. 29 i n.; J. Targalski, Kres jugokomunizmu. Mechanizmy demontażu komunizmu na przykładzie Stowenii i Serbii (1986-1991), Poznań 2011, s. 201 i n.; D. Wybranowski, Między niepodległościq a dezintegracja. Bośnia $i$ Hercegowina $w$ XX $i$ XXI wieku, Szczecin 2011, s. 180 i n.

2 Por. m.in. B. Koszel, Mitteleuropa rediviva? Europa Środkowo- $i$ PołudniowoWschodnia w polityce zjednoczonych Niemiec, Poznań 1999, s. 246 i n.; L. Podhorodecki, Jugostawia. Dzieje narodów, państw i rozpad federacji, Warszawa 2000, s. 198 i n.; M. Kuczyński, Krwawiqca Europa. Konflikty zbrojne i punkty zapalne w latach 1990-2000, Warszawa 2001, s. 171; S. Wojciechowski, Integracja i dezintegracja Jugosławii na przełomie XX i XXI wieku, Poznań 2002, s. 70 i n.; M. Waldenberg, dz. cyt., s. 134 i n.; О. Валецкий, Югославская война 1991-1995 ге, Москва 2006, s. 8 і n., 23 і n.; W. Walkiewicz, Jugosławia. Państwa sukcesyjne, Warszawa 2009, s. 255; S.L. Szczesio, Polityka Stanów Zjednoczonych Ameryki wobec rozpadu Jugosławii w latach 1990-1991, „Acta Universitatis 
przystać na niezależność Słowenii po zakończeniu trwającej 10 dni wojny, o tyle sytuacja wyglądała znacznie gorzej na obszarze Chorwacji, gdzie odnowiły się ostre animozje serbsko-chorwackie. W przypadku Słowenii, z uwagi na jej oddalenie od centrum SFRJ i bardzo niewielki procent ludności serbskiej, Belgrad mógł sobie jeszcze pozwolić na rezygnację z wpływu na reperkusje niezależności tej zamożnej ekonomicznie byłej republiki związkowej. Natomiast Serbowie, stanowiący dość liczną mniejszość na terenie chorwackiej Slawonii, Baranji, Sremu i Pogranicza Wojskowego (Vojnej Krajiny) zaczęli dążyć do połączenia się z Serbią. Rezultatem było utworzenie pod wodzą byłego sierżanta armii federalnej, Milana Marticia już w kwietniu 1991 r. Serbskiego Okręgu Autonomicznego (SAO)³. Dodatkowym argumentem wzmacniającym plany bardzo rozległej autonomii czy secesji były powstające od wiosny tego roku serbskie grupy paramilitarne „Tygrysów”, „Białych Orłów” i innych (o czym niżej), których udziałem były akty terroru i „czystek etnicznych" na Chorwatach, co bardzo szybko doprowadziło do eskalacji konfliktu, wzajemnych akcji odwetowych i w efekcie wybuchu wojny serbsko-chorwackiej. Jej apogeum stanowiły ciężkie walki we Wschodniej Slawonii, zwłaszcza o Vukovar i Osijek ${ }^{4}$. Serbowie uzyskali ciche wsparcie ze strony Moskwy, która wspomogła ich dostawami uzbrojenia i wyposażenia oraz obecnością swych żołnierzy w ramach kontyngentu sił Organizacji Narodów Zjednoczonych ${ }^{5}$.

W roku 1991 na tle innych głównych narodów Bośni i Hercegowiny (BiH), tj. Muzułmanów (około 44\%) i Chorwatów (17\%) Serbowie stanowili

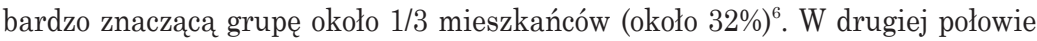
tego roku sytuacja na terenie republiki zaczęła ulegać widocznemu zaostrzeniu,

Lodziensis" 2009, Folia Historica 84, s. 173; J. Kiwerska, Świat w latach 1989-2009. Wydarzenia - konflikty - procesy, Poznań 2009, s. 95; L. Benson, Jugosławia. Historia w zarysie, Kraków 2011, s. 219 i n.

${ }^{3}$ Por. T. Olszański, Mój brat cię zabije!, Warszawa 1995, s. 40 i n.; W. Walkiewicz, dz. cyt., s. 255 .

${ }^{4}$ Por. m.in. D. Pavličević, Historia Chorwacji, Poznań 2004, s. 518 i n.; O. Валецкий, dz. cyt., s. 36 i n., 89-96 i n. (tam również obszernie o walkach o wspomniane wyżej miasta); R. Rybak, Antagonizm serbsko-chorwacki, [w:] Bałkany. Etnokulturowe podtoże konfliktu, red. W. Konarski, A. Koseski, Pułtusk 2006, s. 144; D. Marijan, Oluja, Zagreb 2007, s. 39-40; D. Gibas-Krzak, A. Krzak, Południowosłowiańska mozaika. Charakterystyka geograficzno-polityczna państw postjugosłowiańskich, Szczecin 2010, s. 60.

${ }^{5}$ Por. W. Walkiewicz, dz. cyt., s. 256; S.L. Szczesio, Rosja wobec wojny w Bośni i Hercegowinie w latach 1992-1995, [w:] Rosja współczesna. Dziedzictwo i przyszłość, pod red. M. Brody, O. Nadskakuły, A. Płaczka, Toruń 2010, s. 265.

${ }^{6}$ Por. S. Wojciechowski, dz. cyt., s. 82; P. Eberhardt, Przemiany demograficzno-etniczne na obszarze Jugostawii w XX wieku, Lublin 2005, s. 79; S.L. Szczesio, Droga..., s. 23; D. Gibas-Krzak, Bośnia i Hercegowina-upadek państwa multietnicznego na przełomie XX i XXI wieku. Zarys problemu, [w:] Bośnia i Hercegowina 15 lat po Dayton. Przeszłość teraźniejszość - perspektywy. Studia i szkice, pod red. P. Chmielewskiego i S.L. Szczesio, Łódź 2011, s. 284. 
na co zresztą wpływ miało oderwanie się od federacji Słowenii i Chorwacji oraz obecność w BiH sił Jugosłowiańskiej Armii Ludowej (JNA). Politycy i działacze serbscy, szczególnie Radovan Karadžić - lider Serbskiej Partii Demokratycznej (SDS) i przyszły prezydent Republiki Serbskiej (RS), Biljana Plavšić, Nikola Koljević i Momčilo Krajišnik, obawiali się powstania niepodległej Bośni i Hercegowiny - „państwa islamskiego" z wiodąca rolą Muzułmanów, Aliji Izetbegovicia i jego Partii Akcji Demokratycznej (SDA), w którym Serbowie mieliby pozycję podrzędna? ${ }^{7}$. W związku z tym coraz bardziej widoczną opcją stały się przygotowania do secesji, której ośrodkiem w kwietniu 1991 r. była początkowo Bosanska Krajina z Banja Luka. W czasie od kwietnia do listopada 1991 r. ludność serbska zaczęła tworzyć na obszarze istniejących wówczas 51 okręgów administracyjnych $\mathrm{BiH}$ (z czego 11 ze znaczną mniejszością muzułmańska) 6 terytoriów jako serbskie okręgi autonomiczne ${ }^{8}$. Były to kolejno:

- SAO Krajiny, z głównym ośrodkiem w Banja Luce, powstały w kwietniu 1991 r., złożony z 15 okręgów Bośni Zachodniej. Był on początkowo największy pod względem zajmowanego obszaru, jednak po powstaniu kolejnego obszaru o bardzo podobnej nazwie „Krajina” w Chorwacji, zmienił nazwę na SAO Bosanska Krajina.

- SAO Północno-Wschodni (SAO Severoistočna Bosna) z ośrodkiem w Bijeljinie, został utworzony we wrześniu 1991 r. Tworzyło go 5 okręgów. Po kilku miesiącach od jego powstania, w listopadzie, nazwa uległa zmianie na Šemberija. Ostatecznie w grudniu 1991 r. pełna nazwa brzmiała: SAO Šemberija i Majevica9.

- SAO Hercegowina, z Bilećą jako głównym ośrodkiem administracyjnym, powstały także we wrześniu $1991 \mathrm{r}$. Ten obszar autonomiczny składał się z 7 okręgów położonych na terenie południowo-wschodniej i wschodniej Hercegowiny.

- SAO Ozren-Posavina z ośrodkiem administracyjnym w Doboju w północnej Bośni, powstał w listopadzie 1991 r., tworzył go przede wszystkim okręg Doboj.

- SAO Romanija-Birač z ośrodkiem władzy w Pale, utworzony w listopadzie 1991 r. z połączenia 2 okręgów autonomicznych - Romaniji i Birača, które były złożone łącznie z 15 okręgów.

- SAO Severna Posavina/Północna Posawina planowano utworzyć z okręgów, w których przewagę mieli Muzułmanie i Chorwaci na terenie północnej części Bośni, nigdy jednak w pełni jego granic nie ustalono.

${ }^{7} \mathrm{Na}$ temat procesu przebiegu powstawania poszczególnych SAO i ówczesnej sytuacji, zob. więcej w M. Dobbs, Precz z Wielkim Bratem. Upadek imperium radzieckiego, Poznań 1998, s. 505; S.L. Szczesio, Droga..., s. 33.

8 Por. S. Čekić, Agresija na Republiku Bosnu i Hercegovinu, Planiranje, priprema, izveđenje, knj. II, Sarajevo 2004, s. 801; N. Thomas, K. Mikulan, Yugoslav Wars (2). Bosnia, Kosovo and Macedonia 1992-2001, Oxford 2006, s. 9.

9 Tamże; О. Валецкий, $d z$. cyt., s. 182-183 (tam też szerzej o genezie i procesie tworzenia poszczególnych SAO i zabiegach polityków serbskich w tej mierze). 
Od pierwszych miesięcy 1991 r. SDA próbowała podjąć kwestię deklaracji suwerenności w republikańskiej Skupsztinie, co jednak początkowo nie przyniosło rezultatu. Sytuacja uległa radykalnej zmianie 14-15 listopada podczas obrad wspomnianego parlamentu, co wywołało gwałtowny sprzeciw Serbów i samego R. Karadžicia. Wydarzenia te przyspieszyły również tendencje secesyjne u Chorwatów (powstanie w listopadzie Bosanskiej Posaviny z ośrodkiem w Bosanskim Brodzie i następnie Chorwackiej Wspólnoty Herceg-Bośni), a także w środowiskach serbskich (wyrazem tego było m.in. powołanie 24 października Skupsztiny Serbskiej BiH). Należy zaznaczyć, że zarówno Chorwaci i Franjo Tuđman oraz ludzie z bośniackiej Chorwackiej Wspólnoty Demokratycznej (HDZ), jak i Serbowie obawiali się władzy „Turków” i „fundamentalistów islamskich” A. Izetbegovicia, stąd też traktowali Bośnię jako teren do potencjalnego podziału między siebie i „państwo sezonowe” ${ }^{\text {. }}$.

Dalszymi krokami było przeprowadzone nieformalne serbskie referendum dotyczące niepodległości okręgów serbskich (9-10 listopada) i proklamowanie na początku stycznia 1992 r. Republiki Serbskiego Narodu Bośni i Hercegowiny, co było m.in. efektem połączenia przez R. Karadžicia wspomnianych $\mathrm{SAO}^{11}$. Oficjalnie na przestrzeni marca-sierpnia 1992 r. została ona przemianowana na Republikę Serbską. Jej stolica pierwotnie miała się znaleźć na obszarze kontrolowanych przez Serbów dzielnic Sarajewa (Ilidža, Vogošča i Nowe Sarajewo lub „Serbskie Sarajewo"- Srpske Sarajevo) ${ }^{12}$. Faktycznie jednak przez niemal cały okres konfliktu i pierwsze lata powojenne funkcje stołeczne pełniła niewielka miejscowość uzdrowiskowa, położona około $20 \mathrm{~km}$ na południe - Pale.

Gdy 3 marca 1992 r. niepodległość Republiki Bośni i Hercegowiny kierowanej przez Muzułmanów i Chorwatów stała się faktem, dotychczasowe garnizony armii federalnej niemal natychmiast zaczęły być traktowane jako symbol obecności militarnej „obcego państwa”. Muzułmański rząd nowo powstałego państwa naprawdę miał się czego obawiać, bo zgromadzony tam potencjał wojsk fede-

${ }^{10} \mathrm{Na}$ temat tajnych porozumień w Karađorđevie, Grazu i Tikveš między Franjo Borasem (zaufanym człowiekiem F. Tuđmana) i N. Koljeviciem, wysłannikiem R. Karadžicia, w latach 1991-1992 w sprawie rozbioru Bośni, por. m.in. S.L. Szczesio, Droga..., s. 36; P. Żurek, Bośnia i Hercegowina w wizji politycznej Franjo Tuđmana, [w:] Bośnia i Hercegowina 15 lat..., s. 20; D. Wybranowski, Między niepodległościq..., s. 210 .

11 Jej obszar o powierzchni 17,6 tys. km² i ludności ponad 1,19 mln miał w założeniu objać SAO, enklawy i „te obszary, gdzie naród serbski jest mniejszością wskutek ludobójstwa dokonanego na nim w toku II wojny światowej”. Por. B. Zieliński, Kalendarium procesów integracyjnych $i$ dezintegracyjnych na ziemiach dawnej Jugosławii, „Sprawy Narodowościowe” 1993, t. II, z. 1, s. 200; S.L. Szczesio, Droga..., s. 34-35; D. Wybranowski, Między niepodległościq..., s. 197.

12 N. Thomas, K. Mikulan, dz. cyt., s. 9. Na temat dzielnic Sarajewa w składzie Republiki Serbskiej por. О. Валецкий, dz. cyt., s. 158. 
ralnych był bardzo duży nie tylko w skali lokalnej, ale i całego obszaru SFRJ ${ }^{13}$. Wobec słabości powstającej dopiero armii bośniackiej (i widocznej już słabej konsolidacji wewnętrznej kraju) mogło się to teoretycznie okazać rozstrzygającym argumentem siłowym dla utrzymania $\mathrm{BiH}$ pod kontrola władz w Belgradzie. Jak podaje bowiem jeden z dowódców byłej JNA, gen.-płk Jovo Ninković, na poczatku 1992 r. siły armii federalnej rozlokowane na obszarze republiki BiH w ramach 2. (Sarajewskiego) Okręgu Wojskowego (Vojni Okrug) liczyły w przybliżeniu 90-100 tys. żołnierzy, 750-800 czołgów (i najprawdopodobniej dział samobieżnych), 1 tys. transporterów opancerzonych (i prawdopodobnie także bojowych wozów piechoty), około 4 tys. dział i wyrzutni rakietowych ${ }^{14}$. Jednakże do końca czerwca tego roku wszystkie jednostki JNA pozostałe na terytorium Bośni miały się ewakuować i opuścić kraj, co zresztą częściowo się stało.

Sytuacje w republice cały czas bacznie obserwował Slobodan Milošević, który wydał jeszcze w styczniu tajny rozkaz, by oficerowie armii federalnej, którzy urodzili się w Bośni, zostali tam przeniesieni. To posunięcie dobrze przygotowało grunt pod utworzenie serbskich sił zbrojnych i przyszłe docelowe połączenie obszarów serbskich z Jugosławią. Jeśli doda się do tego żołnierzy niższych stopniem, to około 85\% sił JNA w BiH stanowili wtedy bośniaccy Serbowie ${ }^{15}$. Niemal przez cały okres 1991-1995 istniało ciche przymierze między ekipą R. Karadžicia a rządem Jugosławii oraz S. Miloševiciem, a żołnierze armii federalnej w $1992 \mathrm{r}$. wzięli po stronie serbskiej udział w walkach z Muzułmanami i Chorwatami ${ }^{16}$.

Nie dziwi zatem absolutnie, że Krunoslav Mikulan i Nigel Thomas wskazali, że „kraj opuściło tylko około 14 tys. wojska”. Pozostałe około 80 tys. żołnierzy

${ }^{13}$ Szerzej na temat obecności militarnej JNA na terenie BiH w latach 1991-1992, szczegółowy wykaz jej jednostek i ich dyslokacji, por. S. Čekić, dz. cyt., s. 770.

${ }_{14}$ Por. J. Ninković, Etnička strana ratova u Jugoslaviji 1991-1995, Beograd 2002, s. 155. Takie same dane, lub bardzo zbliżone, u jednego z dowódców muzułmańskiej armii i jedynego z jej najwyższych oficerów pochodzenia serbskiego - gen. Jovana Divjaka. Por. J. Divjak, The First Phase 1992-1993. Struggle for Survival and Genesis of the Army of Bosnia-Herzegovina, [w:] The War in Croatia and Bosnia and Herzegovina 1992-1995, eds. B. Magaš, I. Žanić, London 2001, s. 162; S. Čekić, dz. cyt., s. 771; S.L. Szczesio, Droga..., s. 31.

15 Por. L. Silber, A. Little, Yugoslavia. Death of Nation, New York 1997, s. 217-218; S.L. Szczesio, Droga..., s. 37.

${ }^{16}$ Między innymi część sił JNA wzięła pod szyldem VRS udział w walkach o zdobycie Zvornika czy jako armia federalna na samym początku walk np. o Sarajewo i Mostar. Na temat współpracy między Serbami bośniackimi i rządem w Pale a S. Miloševiciem i różnorodnych form pomocy lub wsparcia na forum dyplomatycznym ze strony Belgradu, por. w ostatnich latach m.in.: S. Čekić, dz. cyt., s. 802 i n.; M. Korzeniewska-Wiszniewska, Serbia pod rzqdami Slobodana Miloševicia. Serbska polityka wobec rozpadu Jugostawii w latach dziewięćdziesiatych XX wieku, Kraków 2008, s. 98 i n.; K. Pawłowski, Polityka Federacyjnej Republiki Jugosławii wobec konfliktu zbrojnego w Bośni i Hercegowinie (19921995), [w:] Bośnia i Hercegowina 15 lat..., s. 146 i n. 
rozpoczęło nową służbę w szeregach bardzo dynamicznie tworzonej Armii Republiki Serbskiej (VRS) jako „ochotnicy” (dobrovoljci) ${ }^{17} .12$ maja 1992 r. w byłej Kwaterze Głównej JNA w Banja Luce VRS została powołana do życia ${ }^{18}$. Prawnie stało się to na posiedzeniu Ludowej Skupsztiny w Banja Luce, gdy uchwalono stosowną ustawę. Formalnie naczelnym wodzem był prezydent R. Karadžić, jednak faktyczne dowództwo wojskowe sprawował Serb, gen.-mjr (potem od 1994 r. gen.-płk) Ratko Mladić, były zwierzchnik 2. Okręgu Wojskowego JNA ${ }^{19}$. W pierwszych latach wojny jego zastępcą był gen.-ppłk Milan Gvero, a szefem sztabu gen.-ppłk (następnie gen.-płk) Manojlo Milovanović. Pion logistyki podlegał natomiast gen.-mjr. Đorđe Đukiciovi, bezpieczeństwa płk. Zdravko Tolimirovi, a rekrutacji i mobilizacji płk. Mićo Gruborovi ${ }^{20}$.

Schyłek lat 80. i początek 90 . ubiegłego wieku to bardzo dynamiczny proces budzenia się poczucia odrębności i potrzeby samookreślenia u poszczególnych narodów zamieszkujących ówczesną SFRJ. Od tej pory stopniowo przestano używać powszechnie wcześniej stosowanego określenia „Jugosłowianin”, natomiast czymś istotnym stała się deklaracja przynależności typowo etnicznej w wąskim zakresie - ważne od tej pory było czy ktoś jest np. „Serbem”, „Chorwatem” czy „Muzułmaninem”. Symptomy te były widoczne coraz bardziej także i w szere-

17 S. Čekić, dz. cyt., s 798 i n.; N. Thomas, K. Mikulan, dz. cyt., s. 12.

18 Por. m.in. S. Čekić, dz. cyt., s. 838-840; Vojska Republike Srpske, http://www. republikasrpska. net/istorija/vojska-republike-srpske-/?lang=lat.

19 Ratko Mladić urodził się w marcu 1942 (lub 1943) r. we wsi Božinovci koło Kalinovika w południowo-wschodniej Bośni. Jego ojciec Neđo był partyzantem, który zginą z rąk ustaszy. Jak wspominał sam generał, „nie zna miejsca grobu swego ojca”. Śmierć ojca i pamięć o nim wywarły ogromny wpływ na Mladicia, który dorastał w atmosferze chęci zemsty na Chorwatach, do czego doszła potem niechęć do „Turków”. Jako żołnierz rozpoczął służbę i naukę w szkole wojskowej w Skopje w 1965 r. We wczesnej młodości i w realiach systemu politycznego stworzonego przez Titę deklarował się jako „Jugosłowianin”, dopiero potem zaczął określać siebie jako „Serb”. Będąc wysokim rangą oficerem JNA w randze gen.-por. pełnił od 1989 do 1991 r. funkcję dowódcy 3. Okręgu Wojskowego w Skopje. Od 1991 r. brał udział, jako dowódca 9. Korpusu JNA, w walkach o chorwacki Knin. Do początku 1992 r. R. Mladić był komendantem 2. Okręgu Wojskowego w Sarajewie. W maju tego roku wystapił z armii federalnej i następnie został - w porozumieniu z prezydentem R. Karadžiciem oraz parlamentem Serbów bośniackich - faktycznym naczelnym wodzem nowo powstajacej VRS. Por. Ko je general Mladić?, http://www.camo.ch/ko_ je_mladic. htm; Profile: Ratko Mladic: Bosnian Serb army chief, http://news.bbc.co.uk/2/hi1423551. htm; D. Wybranowski, Między niepodległościq..., s. 203. W ostatnich latach na jego temat zob. m.in. T. Judah, The Serbs. History, Myth and the Destruction of Yugoslavia, New Haven 2009, ponadto książki publicystki i biografistki generała, Ljiljany Bulatović, Raport komandanta, Beograd 2009 oraz Raport komandanta-u ogledanju epohe, Beograd 2011. Por. także General prvi pročitao „Raport 2", http://www.vesti-online.com/Vesti/Srbija /189568/General-prvi-procitao_Raport-2-/print.

${ }_{20}$ Por. S. Čekić, dz. cyt., s. 842 i n. 
gach JNA ${ }^{21}$. Powrót do tradycji i symboliki z czasów istnienia Królestwa Jugosławii i czetników gen. Dragoljuba/Dražy Mihailovicia z czasów II wojny światowej nastapił również w bardzo widocznym zakresie u Serbów.

Powstające w szybkim tempie w pierwszej połowie 1992 r. siły VRS, serbskie formacje paramilitarne i ochotnicze, zaczęły przejmować skazane wcześniej na potępienie i damnatio memoriae za rządów Josipa Broz-Tity zwyczaje i symbole czetników. Szybko też zamieniono sztandary SFRJ i czerwone gwiazdy na trójkolorowe flagi Serbii królewskiej z białym dwugłowym orłem i bizantyńskim krzyżem z czterema symbolami „C” (poczwórne „S” pisane cyrylica: Camo Слога Србина Спасава - Tylko jedność ocali Serbów). Często też były widoczne w siłach serbskich czarne, czetnickie sztandary z trupimi czaszkami i piszczelami, zdobne napisami „С Вјером у Бога. Свобода или Смрт!” (Z wiara w Boga. Wolność lub śmierć), nawiązujące do tradycji jeszcze z czasów wojen z Turkami.

Modą stało się też noszenie długich włosów i zapuszczanie przez oficerów i żołnierzy bród, podobnie jak czynili to kilkadziesiąt lat wcześniej ludzie „od Mihailovicia”. Dotychczasowe mundury wyjściowe armii federalnej zaczęły być zastępowane uniformami i elementami umundurowania nawiązującymi do czasów dynastii Karađorđeviciów ${ }^{22}$. Często też łączono w różny sposób używane do tej pory mundury polowe z czapkami o ,czetnickim” fasonie i wyglądzie oraz tradycyjnymi ludowymi czapami z owczej wełny z nowymi narodowymi znakami. Okragłe emblematy w barwach narodowych na czapkach, serbski tricolor - czerwony-niebieski-biały oraz biały dwugłowy orzeł z widniejąca nad nim koroną zamkniętą były chętnie umieszczane na różnego rodzaju sztandarach i emblematach poszczególnych jednostek (od szczebla korpusu i brygad VRS po różnego rodzaju samodzielne grupy operacyjne i siły ochotnicze czy paramilitarne) bądź na rękawach mundurów ${ }^{23}$. Miano „czetników” zaczęło znów być powszechnie używane na określenie żołnierzy serbskich i Serbów w ogóle.

${ }^{21} \mathrm{Na}$ przykład coraz częściej żołnierze chorwaccy z armii federalnej używali historycznej symboliki i flag, pozbawionych jednak znaku ustaszy - „U”[staša] z czasów istnienia NDH, który miał dosyć negatywną konotację. Powszechną praktyką stało się zastępowanie czerwonych komunistycznych gwiazd tradycyjna, biało-czerwoną szachownica, umieszczaną na czapkach czy rękawach uniformów oraz flagach narodowych i choragwiach tworzonych od 1991-1992 r. jednostek. Mimo pewnych oporów, następowało dosyć szybkie odradzanie się tradycji ustaszy, a ich mniej lub bardziej widoczna symbolika, wsparta narastającym udziałem księży w armii jako kapelanów, podobnie jak katolickie krzyże i różańce coraz częściej były w widoczny sposób eksponowane przez młodych narodowców i różne subkultury. Por. M.J. Zacharias, dz. cyt., s. 491-492.

${ }^{22}$ Por. m.in. film Četnici 1991-1995, http://www.youtube.com/watch?v=57YBMceU4.

${ }_{23}$ Por. zestawienie emblematów i symboli poszczególnych korpusów, brygad i innych jednostek serbskich: Republic of Srpska Army VRS, Vojska Republike Srpske, http:// webspace.webring.com/people/uk/kokosar2000?RS_army.html. 
W powstajacych siłach zbrojnych przyszłych przeciwników miejsce komunistycznych oficerów politycznych stopniowo zaczęli zajmować duchowni - u Chorwatów księża katoliccy, u Muzułmanów imamowie, a u Serbów prawosławni popi. Coraz częściej też zaczęła być stosowana symbolika religijna i praktyki mszy świętych ${ }^{24}$. W powstających serbskich siłach zbrojnych i tworzonych formacjach paramilitarnych liczni popi znaleźli swe miejsce jako kapelani polowi, a Serbska Cerkiew Prawosławna udzieliła swego poparcia duchowego, co skrzętnie było wykorzystane jako argument propagandowy u przeciwników Serbów, jako kolejny element apologii serbskich podbojów i wsparcia idei „Wielkiej Serbii” ${ }^{25}$. Przypadki „czystek etnicznych” dokonywanych przez wojska serbskie i relacje uchodźców zarówno Muzułmanów, jak i Chorwatów oraz zachodnich mediów, wrogo nastawionych z różnych powodów do Serbów, często pokazywane w światowych telewizjach, ukazywały ich jako „zbrodniarzy”, „morderców” czy „bałkańskich dzikusów”26. Ten obraz utrwalony został przez powstające filmy fabularne (także w Polsce) mające ogromną widownię ${ }^{27}$.

${ }^{24}$ Por. Garda Panteri - Ljubiša Savić Mauzer, http://www.youtube.com/watch?$\mathrm{v}=$ HowvCWD9348feature $=$ related.

25 Por. Uloga Srpske Pravoslavne Crkve u agresiji na BiH, http://www.islambosna. ba/tekstovi-i-knjige/politika/26497-uloga-srpske-pravoslavne...; Srpska Pravoslavna Crkva i etničko čišcenje, http://www.bosnjacki-front.net/index.php?docid=320907211511.

${ }^{26} \mathrm{Na}$ temat konkretnych przypadków kształtowania negatywnego wizerunku Serbów w mediach i propagandzie oraz w polityce zachodniej por. m.in. M. Waldenberg, dz. cyt., s. 202-222; M. Poletyło, Propaganda wojenna w liberalnej demokracji. Argument batkański-analiza przypadku, Toruń 2008, s. 95 i n.

27 Takim przykładem jest m.in. film Psy II (1994 r.) w reżyserii Władysława Pasikowskiego, gdzie postacią negatywną był polski handlarz bronią Radosław Wolf (grany przez Artura Żmijewskiego) służący jako najemnik w VRS. W jednej ze scen prologu ukazującej serbską kolumnę zmotoryzowaną po pacyfikacji jakiejś wsi bośniackiej trzyma w rękach ucięte głowy Muzułmanów, co było tak naprawdę propagandową kalką znanego zdjęcia przedstawiającego saudyjskiego mudżahedina z odciętą głową Serba. Inna postać, Rosjanina także służącego w armii bośniackich Serbów, płk. Sawczuka czy opowieści Wolfa miały ukazać w sposób skondensowany okrucieństwa, jakich dopuszczali się żołnierze serbscy wobec Muzułmanów. Kolejny film W. Pasikowskiego - Demony wojny według Goi (1998 r.) - pokazał grupę polskich żołnierzy służących na początku 1996 r. w ramach wojsk IFOR, dowodzonych przez mjr. Kellera (Bogusław Linda) w walce z sadystycznym Škija, serbskim przywódcą okrutnej, międzynarodowej bandy, terroryzującej Bośniaków czy pozbawionego skrupułów polskiego najemnika imieniem Filip, walczącego uprzednio w szeregach VRS. Fatalny obraz Serbów jako „bandytów” i „zbrodniarzy w mundurach” kreowały także takie obrazy, jak m.in. Aleja Snajperów (Welcome to Sarajevo) z 1997 r. w reżyserii Michaela Winterbottoma czy Za liniq wroga (Behind the Enemy Lines) Johna Moore’a z 2001 r. To wszystko było elementem kultury masowej w służbie propagandy mającej ukazać widzowi na świecie „złych Serbów” i „niewinnych”, okrutnie mordowanych Muzułmanów czy Chorwatów, w których obronie wystapił w 1995 r. ze zbrojną interwencją Zachód. 


\section{Rozmieszczenie i struktura wewnętrzna poszczególnych korpusów. Inne jednostki w składzie Armii Republiki Serbskiej}

Przyszła Armia Republiki Serbskiej powstawała w znacznej mierze w miejscach rozmieszczenia niektórych okręgów Obrony Terytorialnej (TO, następnie TORBiH), a zwłaszcza zdominowanych przez Serbów Banja Luki i Doboju, z wykorzystaniem lokalnej milicji, struktur terenowych SDS, dość znacznej liczby rezerwistów i przede wszystkim, jak uprzednio wspomniano, istniejącej struktury militarno-terytorialnej JNA ${ }^{28}$. W pierwszych latach konfliktu bośniackiego powstało ogółem pięć korpusów VRS - wielkich jednostek operacyjnych ${ }^{29}$. Dnia 4 czerwca 1992 r. Sztab Generalny/Główny VRS (Glavni Štab VRS) na mocy rozkazu dziennego $\mathrm{nr}$ 02/5-31 wyznaczył strefy odpowiedzialności istniejących już wielkich jednostek ${ }^{30}$. Część z nich była początkowo odpowiednio przeformowanymi i przekonstruowanymi organizacyjnie dotychczasowymi ośmioma wielkimi jednostkami JNA. W roku 1992 siedziba Sztabu Generalnego znajdowała się w Pale. W celu jego zabezpieczenia powstały jednostki o specjalnym przeznaczeniu: 1. Gwardyjska Brygada Zmotoryzowana (1. Gardijska Motorizovana Brigada), 65. Pułk Ochrony Sztabu Generalnego (Zaštitni Puk Glaunog Štaba) i 67. Pułk Łączności Sztabu Generalnego (67. Puk Veze Glavnog Štaba), ponadto utworzono dla niego Szpital Sztabu Generalnego, Centrum Wojskowo-Szkoleniowe i Informacyjno-Propagandowe ${ }^{31}$. Oprócz tego działał specjalny 10. Oddział Dywersyjny (10. Diverzantski Odred) podporządkowany bezpośrednio gen. R. Mladiciowi ${ }^{32}$. Liczba korpusów w 1995 r. została powiększona do sześciu.

Należy zaznaczyć, że zwłaszcza w latach 1993-1995 poszczególne korpusy przeszły szereg zmian strukturalnych. W miejsce niektórych brygad i innych związków taktycznych powstawały nowe o innej numeracji. W kilku przypadkach część jednostek została odkomenderowana, raz lub nawet kilkakrotnie, ze swego macierzystego obszaru dyslokacji do innego, stosownie do sytuacji na froncie.

${ }_{28}$ Por. J. Ninković, dz. cyt., s. 154; S. Čekić, dz. cyt., s. 801.

${ }^{29}$ Były to: 1. Krajiński (Krajiški) Korpus (kwatera główna Banja Luka), 2. Korpus Krajiński (Drvar), Korpus Wschodniobośniacki (Istočnobosanski, Bijeljina), SarajewskoRomanijski (Serbskie Sarajewo, Pale) i Hercegowiński (Trebinje, Bileća), por. S. Čekić, dz. cyt., s. 841 i n.; Army of Republic Srpska, http://en.academic.ru/dic.nsf/enwiki/192945.

${ }^{30}$ Por. kopia dokumentu Zone odgovornosti $i$ naredni zadaci vojske sr bih, http:// www.nezavisne.com/forum/index.php? PHPSESSID=m5uujag7j7lvk60m7pijk.

${ }^{31}$ Vojne jedinice VRS, http://www.pl.bih.org. Szereg informacji i wykaz poszczególnych jednostek zawiera także zestawienie Ратне јединице ВPC, http://www.nezavisne. com.forum/index.php?PHPSESSID=m51uujag7 jlvk 60m7pjjk.

${ }^{32} \mathrm{Na}$ temat tej jednostki por. Diverzantski odred direktno odgovoran Mladiću, http://www.e-novine.com/region/region-bosna/48385-Diverzantski-odred-direktno-od... 
W siłach lądowych Serbów bośniackich obowiązywało następujące nazewnictwo stosowane przy określeniach poszczególnych jednostek operacyjnych i taktycznych: Dywizja (Divizija), Brygada Pancerna (Oklopna Brigada), Brygada Zmechanizowana (Motorizovana/Mehanizirovana Brigada), Lekka Brygada Piechoty (Laka Pešadijska Brigada), Brygada Górska (Brdska Brigada), Brygada z nazwą odmiejscową i określeniem przeznaczenia bojowego (np. 1. Zvornicka Brigada, 6. Sanska Laka Brigada), Brygada (Brigada - z numerem taktycznym, bez nazwy odmiejscowej), Grupa Operacyjna (Operativna Grupa) Samodzielna Jednostka (Samostalna Jedinica). Z uwagi na przejmowane w różny sposób od armii federalnej jednostki artyleryjskie, złożone z klasycznych armat, haubic i moździerzy, a także formowane jednostki rakietowe (złożone zwłaszcza z kołowych wielolufowych wyrzutni lub zestawów rakiet plot.) tworzono takie formacje, jak „mieszany pułk rakietowy” (mješoviti raketni puk). W przypadku licznych oddziałów paramilitarnych wspierających działania VRS używano sformułowania paravojni jedinice lub paravojni formacije, o których niżej. Dodatkowo uzupełnieniem były jednostki Policji RS (Milicija lub, od 1994 r., Policija Republike Srpske) rozlokowanych w 51 okręgach $^{33}$.

Wspomniane sześć korpusów VRS rozlokowano na następujących obszarach a tworzyły je jednostki:

- 1. Krajiški Korpus z Kwaterą Główną w Banja Luce. Powstał w większości z jednostek uprzednio tworzących 5. Korpus JNA. Jego dowódca był gen.-ppłk, a następnie gen.-płk Momir Talicín ${ }^{34}$. Funkcję szefa sztabu pełnił gen.-mjr Boško Kelečević. Z uwagi na swą wielkość i dosyć, jak się wydaje, zmienna liczbę brygad i innych jednostek, strefa odpowiedzialności i pas działania tego korpusu rozciagały się na absolutną większość kontrolowanej przez Serbów Bosanskiej Krajiny, od granicy chorwackiej na zachodzie po Posawinę ${ }^{35}$. W okresie od maja do grudnia 1992 r. (i w następnych latach) korpus tworzyły m.in.:

${ }^{33}$ N. Thomas, K. Mikulan, dz. cyt., s. 13.

${ }^{34} \mathrm{Na}$ temat osób na stanowiskach dowódczych w poszczególnych korpusach VRS i, w części przypadków, trwania służby poszczególnych generałów, składu korpusu oficerskiego VRS i wydarzeń związanych z działalnością militarna, będącą niekiedy podstawa do oskarżeń o przypadki „zbrodni wojennych” por. akt oskarżenia, stanowiący cenne źródło informacji o VRS, wydany przez Międzynarodowy Trybunał Karny dla byłej Jugosławii (ICTY) z siedzibą w Hadze w sprawie oskarżenia jugosłowiańskiego gen. Momčilo Perišicia: The International Criminal Tribunal for the former Yugoslavia. The Prosecutor of the Tribunal against Momcilo Perisic, http://www.icty.org/x/cases/perisic/ind/en/perii050222e.htm. O aktualnym przebiegu sprawy gen. Perišicia, związkach między VRS i Armią Serbskiej Republiki Krajiny oraz Armią Federacyjnej Republiki Jugosławii (VJ) podczas wojny i przyjmowaniu żołnierzy-weteranów z BiH i Chorwacji po 1995 r. do armii jugosłowiańskiej, a potem serbskiej por. Oficiri VRS i SVK imaju status pripadnika VJ, http://www.kurir-info-rs./vesti/drustvo/oficiri-vrs-i-svk-imaju-status-pripadnika-vj-896.

${ }_{35}$ Por. Vojne jedinice-1. Krajiški Korpus Banja Luka, http://www.plbih.info/cms/ Vojne-jedinice.334.0.html. 
Sztab, Dowództwo i 10. Krajiška Dywizja (rozformowana w końcu 1992 r.), 30./19. Dywizja (lub brygada) Srbobranska (stacjonowała w okolicach Donji Vakufu), 1. i 2. brygady pancerne/zmechanizowane (tu występuje rozbieżność u poszczególnych autorów), 7. Kupreško-Šipovska Brygada Zmotoryzowana, 16. Krajiška Brygada Zmotoryzowana/Zmechanizowana, 27. Derventska i 43. Prijedorska brygady zmechanizowane, 1., 2., 3. i 4. banjaluckie lekkie brygady piechoty, 5. Kozaračka Lekka Brygada Piechoty, 6. Sanska Lekka Brygada Piechoty, 11. Dubička Lekka Brygada Piechoty, 11. Mrkonjićka Lekka Brygada Piechoty, 1. i 2. Ozrenska, 12. Sipovska, 1. Laktaška, 1. Srbačka, 1. Novigradska, 1. Studentska, 1. Čelinačka, 1. Kotorvaroška, 1. Vučijacka, Prnjavorska, 1. Teslićka, Gradiška, Donjevakufska, Dobojska i 1. Trebavska lekkie brygady piechoty. Być może takie jednostki, jak 22. i 31. brygady piechoty i 89. Brygada Artylerii Rakietowej powstały czasowo (lub połączyły się z innymi) ${ }^{36}$. Poza wspomnianymi dywizjami i brygadami w 1 . Korpusie znajdowały się jeszcze kolejne pułki: 1. i 9. mieszane pułki artyleryjskie, 1. Mieszany Pułk Artylerii Przeciwpancernej, 1. Pułk Artylerii Przeciwlotniczej, 1. i 9. Pułk Inżynieryjny. W składzie 1. Korpusu figurowała też Samodzielna Jednostka Muzułmańska „Meša Selimović" (dla uczczenia autora m.in. powieści Twierdza i Derwisz i śmierć) ${ }^{37}$. Uzupełnieniem wspomnianej wielkiej jednostki VRS były m.in. bataliony żandarmerii wojskowej, sanitarny, saperski i pontonowy.

Czasowo w składzie 1. Korpusu działały utworzone grupy taktyczne (ogółem pięć) i operacyjne. Jedna z nich była Grupa Operacyjna „Doboj”, która została stworzona w końcu maja 1992 r. $^{38}$ Znana była także pod nazwami „Serbska

${ }^{36}$ Dosyć dziwna w powyższych zestawieniach wydaje się znaczna liczba brygad oznaczonych numerem „1”, podobnie jak i w innych, które różni jedynie przymiotnik odmiejscowy. Por. 1. Krajiski Korpus, http://www.republikasrpska.forumotion.net/t12-topic. Być może wynikało to z pośpiechu czy spontaniczności lub nawet podkreślenia znaczenia przy formowaniu poszczególnych jednostek w wymiarze lokalnym, nieuniknionego w tym czasie braku pełnej informacji bądź uporządkowania i systematyzacji, które mogły być dopiero potem przezwyciężone przez komplet danych i nowa, bardziej skoordynowaną numerację brygad. Możliwe również, że powodem był inny przydział lub zmiana numeru po restrukturyzacji i przeformowaniu. Inne zestawienie poszczególnych jednostek operacyjnych w składzie 1. Korpusu podaje Republic of Srpska Army...; Ратне јединнице...

${ }^{37}$ Znana była jako Samostalna Muslimanska Jedinica „Meša Selimovič”. Jednostka ta powstała w sierpniu 1992 r. we wsi Kulina koło Derventy z inicjatywy kpt. rezerwy JNA Ismeta Djuhericia i została wsparta przez ówczesnego płk. Slavko Lisicę, dowódcę 3. Grupy Taktycznej/Operacyjnej VRS. Oddział (określany mocno na wyrost jako „batalion”) liczył sobie około 120 ludzi, tj. miał etat nieco wzmocnionej kompanii i do stycznia 1993 r. był dowodzony przez wspomnianego I. Djuhericia. Po nim, aż do końca konfliktu, komendę sprawował Nusret Dizdarević, por. Istorija Dervente-Lisica-komandant po potrebi, http://derventa. webs.com/sjecanjageneralalisice.htm; V. Popović, N. Smiljić, Branio svoje, tugovao za Jugom, http://www.novosti.rs/vesti/naslovna/aktuelno.69.html:144830-Branio-svoje-tugavao-...

${ }^{38}$ Por. Republic of Srpska Army... 
Brygada Vučijak" lub OG-9 i działała w rejonie Doboju i Odžaka. Dowódcami Grupy Operacyjnej „Doboj” byli płk Milivoj Simić, a następnie gen.-płk Vladimir Arsić, szefem sztabu zaś płk Novak Đukić3 ${ }^{39}$. W jej składzie miały znaleźć się takie jednostki, jak: 2. Brygada Pancerna, 27. Brygada Zmechanizowana, 1. i 2. teslićke lekkie brygady piechoty, 1., 2., 3. i 4. ozrenskie lekkie brygady piechoty, 1. Trebavska, 1. Krnjinska, 1. Dobojska i 1. Vučijacka lekkie brygady piechoty. Ponadto w jej składzie znajdowały się trzy bataliony: 1. batalion (wcześniej Dugopoljski), 2. batalion (Podnoski) i 3. batalion (Trnjanski). Uzupełnieniem ogniowym były trzy baterie moździerzy ${ }^{40}$. W składzie 1 . Korpusu znalazły się jeszcze inne grupy operacyjne (,Vlašić” i „Prijedor”) ${ }^{41}$.

Jak podaja niektóre zestawienia, w składzie korpusu były w $1993 \mathrm{r}$. m.in. następujące jednostki: 41. Dywizja Piechoty, 7. i 149. brygady piechoty, 145. Brygada Zmotoryzowana, 417. Pułk Artylerii, 5. Pułk Artylerii Przeciwlotniczej, 552. Pułk Inżynieryjny ${ }^{42}$. Bardzo możliwe, że korpus przechodził restrukturyzację lub zmianę numeracji jednostek, gdyż rosyjski autor opisujący wojnę w byłej Jugosławii, Oleg Waleckij, wymienia siedem brygad (101., 102., 109., 111., 115., 142. i 155.) i pięć oddzielnych batalionów. Według tego autora stan tej jednostki miał w roku 1995 wzrosnąć łącznie do dziewięciu brygad, tj.: 1., 2., 5., 15., 101., 102., 105. zmechanizowane i 1. i 2. górskie ${ }^{43}$. W każdym razie, w zależności od źródła informacji, w przypadku 1. Korpusu widać daleko idące niekiedy rozbieżności w liczbie poszczególnych jednostek i ich numeracji. Z powyższego zestawienia wynika jednak, że wspomniana jednostka była chyba najlepiej uzbrojona i wyposażona w sprzęt pancerny, zmechanizowany i ciężką artylerię. Brała także udział w większości walk i kampanii prowadzonych przez Serbów na najtrudniejszych odcinkach tej wojny.

- 2. Krajiški Korpus z Kwaterą Główną w Drvarze (złożony w dużej mierze z sił Korpusu Bihackiego JNA) był rozlokowany na terenie środkowo-zachodniej i północno-zachodniej części Bośni. Dowodzili nim gen.-mjr Grujo Borić, a następnie gen.-mjr Radivoj Tomanić. Szefami sztabu byli gen.-mjr Mićo Vlaisalvljević i płk (następnie gen.-ppłk) Dušan Kukobat. Wspomniany korpus tworzyły początkowo następujące siły: 7. Brygada Zmotoryzowana (stacjonująca w Kupres po jego zdobyciu), 1. Lekka Brygada Piechoty (Novigrad) i 5. Brygada Górska (Drvar), 3. Lekka Brygada Piechoty (Bosanski Petrovac), 9. Lekka

${ }^{39}$ Ратне јединнице...; Pukovnik Milovan Milutinovic: Kako je smenjivan general Ratko Mladic, http:/www.nin.co.rs/arhiva/2408/1.html.

40 Tamize.

${ }^{41}$ Por. 1. Krajiški Korpus-Encyklopedia, http://bs.efactory.pl/1_krajiC5\%A1ki_ KOrpus_Vojske_Republike_Srpske.

${ }^{42}$ Por. Army of Republic of Srpska (Vojska Republike Srpske - VRS). Order of Battle 1993, http://www.vojska.net/eng/armed-forces/bosnia-and-herzegovina/vrs/organization/1993/.

43 О. Валецкий, dz. cyt., s. 207. 
Brygada Piechoty (Grahovo), 11. Lekka Brygada Piechoty (Bosanska Krupa), 15. Lekka Brygada Piechoty (okolice Bihacia), 17. Lekka Brygada Piechoty (Ključ), 18. Lekka Brygada Piechoty (Glamoč), 13. Brygada Piechoty, ponadto trzy mieszane pułki artylerii.

W roku 1993 w składzie 2. Korpusu znalazły się: 4. Brygada Pancerna, 12., 140(?). i 257(?). brygady zmechanizowane, 10. Pułk Artylerii Przeciwlotni$\operatorname{czej}^{44}$. Jak podaja niektóre zestawienia jednostek, korpus ten tworzyły w roku 1994: 1. Lekka Brygada Piechoty (Drvar), 2. Lekka Brygada (Mrkonjić Grad), 15. Brygada Piechoty (okolice Bihacia), 17. Lekka Brygada Piechoty (Bosanska Krupa), 6. Brygada Piechoty (Sanski Most).

- Wschodniobośniacki (Istočno-Bosanski) Korpus z Kwaterą Główną w Bijeljinie. Był złożony w większości z sił tworzących były Korpus Tuzlanski JNA na obszarze Serbskiego Okręgu Autonomicznego Šemberija i Majevica. Jego dowódcami byli początkowo pułkownicy Nikola Denčić i Dragutin Ilić, a następnie gen.-mjr Novica Simić. Funkcję szefa sztabu sprawował ppłk Rudenko Gengo, a od 1994 r. gen.-mjr Budimir Gavrić. W roku 1992 3. Korpus tworzyły: 1., 2. i 3. posawińskie brygady, 1., 2. i 3. Šemberijsko/Šembersko-Majevickie brygady, 1. Bijeljinska Lekka Brygada oraz 1. Zvornicka Brygada (potem przydzielona do 5. Korpusu Drina), ponadto trzy pułki artylerii mieszanej.

Natomiast w 1993 r. w składzie wspomnianego korpusu były następujace jednostki: 2. i 195. brygady zmotoryzowane, 6., 11. i 29. brygady piechoty, 45. Pułk Artylerii, 17. Pułk Artylerii Przeciwlotniczej i 17. Pułk Inżynieryjny. Był on pod względem liczebności jednostek jednym z najsilniejszych ugrupowań VRS. Po kolejnych zmianach i przetasowaniach podczas wojny w roku 1993 tworzyły go: 5., 6., 10., 49., 145. i 437(?). brygady zmechanizowane (być może tak wysoka numeracja dotyczy pułku, a nie brygady), 19. i 215(?). brygady górskie, 208. Pułk Artylerii i 4. Pułk Obrony Przeciwlotniczej.

- Korpus Sarajewsko-Romanijski rozlokowany na terenie SAO Romanija-Birač, obejmował w głównym zarysie obszar 2. Okręgu Wojskowego. Pod względem formalnym powstał z rozkazu gen. R. Mladicia 22 maja 1992 r. Jego Kwatera Główna znalazła się w Pale i na terenach serbskiej części Sarajewa. Dowodzili nim początkowo generałowie Vojislav Djurdevac i Tomislav Šipčić, a od września 1992 r. aż do sierpnia 1994 r. gen.-mjr Stanislav Galić. Jego następcą aż do końca wojny był gen.-mjr Dragomir Milošević. Główną bazę organizacyjną tworzyły siły 4 . Korpusu JNA, a jednostki korpusu liczyły sobie około 18 tys. ludzi tworzacych związek operacyjny złożony z 10-13 brygad. W jego składzie znalazły się: 1 . Sarajewska Brygada Zmotoryzowana (rozlokowana w zdobytej części Sarajewa, tj. w Grbavicy i Lukavicy), 2. Romanijska Brygada Zmotoryzowana/Lekka (Knežina-Sokolac), 1. Romanijska Brygada Piechoty (Pale, Han Pijesak), Igmańska Brygada Piechoty (Blažuj, Hadžici), Ilidžanska Brygada Piechoty (Sarajewo-Ilidža), 3. Novosarajevska Brygada Piechoty

${ }_{44}$ Tamíe. 
(Sarajewo-Grbavica) ${ }^{45}$. Ponadto brygady piechoty znajdowały się w Vogošcy, Rajlovacu, Rogaticy i Trnovie. Do korpusu przydzielono ponadto dwie jednostki - pierwsza o charakterze specjalnym „Białe Wilki” (Beli Vukovi) ${ }^{46}$, a druga to Serbska Straż/Gwardia „Ilidža” (Srpska Garda Ilidža). W składzie wspomnianego korpusu znalazły się również bataliony: żandarmerii wojskowej, sanitarny, bezpieczeństwa i transportowy. Wokół Pale Serbowie ulokowali aż cztery pułki artylerii i cztery bataliony sił bezpieczeństwa wewnętrznego. Uzupełnieniem całości tych sił były jednostki inżynieryjne zgrupowane w Lukavicy. Na jesieni 1992 r. korpus przeszedł pierwszą reorganizację, gdy brygady Trnovska i Novosarajevska weszły w skład 1. Romanijskiej, a brygady Hadžicka i Blažujska zasiliły Igmańską Brygadę Piechoty. U schyłku tego roku wspomniane już brygady Romanijska i Rogaticka zostały przydzielone do Korpusu Drina. Na przełomie 1993 i 1994 r. brygady Rajlovacka, Vogoščanska i sformowana wówczas Koševska weszły w skład nowo utworzonej i wspominanej uprzednio 3. Brygady Sarajewskiej. Tym samym liczba brygad w korpusie wynosiła w tym czasie według niektórych danych ogółem siedem ${ }^{47}$. Jak wskazał O. Waleckij, w 1995 r. miała ona stopniowo wzrosnąć do dziewięciu ${ }^{48}$.

- Korpus Drina powstał u schyłku wojny w 1995 r. i sformowano go z części jednostek ze składu korpusów Sarajewsko-Romanijskiego i Hercegowińskiego. Dowodzili nim gen.-mjr Milenko Živanović (do lipca 1995 r.), a następnie do końca wojny płk (później gen.-ppłk) Radislav Krstić. Szefami sztabu byli gen.-mjr Milutin Śkočajić, wcześniej wspomniany R. Krstić i ostatecznie płk Svetozar Andrić. Korpus Drina działał na obszarze północno-wschodniej Bośni. Rejon operacyjny to okolice Srebrenicy, Žepy, Sokolaca i Bratunaca. Jego Kwatera Główna znalazła się we Vlašenicy. Korpus tworzyły w przeciagu kilku lat takie jednostki, jak: 2. Romanijska Brygada Zmotoryzowana (kwatera główna w Sokolacu), 1. i 2. Zvornicka Brygada (uprzednio w 3. Korpusie), 7. Brygada (kwatera główna - Bratunac), 1. i 8. brygady (Drińskie), 11. Skelanska Brygada Piechoty. Potem przybyły jeszcze 1. Vlašenicka Lekka Brygada, 1. Biračka Lekka Brygada Piechoty i 1. Milićka Lekka Brygada Piechoty oraz 5. Podrinjska Lekka Brygada Piechoty. Jako istotne uzupełnienie przy korpusie przydział uzyskała jednostka sił specjalnych „Wilki Driny” (Vukovi od Drini) - oddział powołany z części żołnierzy służących uprzednio w 1 . Brygadzie Zvornickiej. Jej dowódca został kpt. Mile Stanašević, a istniejący etat ustalono w sile batalionu (542 ludzi), z czego w walkach poległo 82. Ponadto korpus wspomagały jednostki inżynieryjne i żandarmerii wojskowej. W roku 1995 skład tej wielkiej jednostki wyniósł 15 tys. żołnierzy w ramach istniejaccych 11-13 brygad $^{49}$.
${ }^{45}$ Por. tamże, s. 205.
${ }^{46}$ Tamże, s. 327.
47 Tamize, s. 205.
48 Tamże.
${ }^{49}$ Republic of Srpska Army... 
- Korpus Hercegowiński (Hercegovački, uprzednio były Korpus JNA, Trebinje-Bileća) powstał w maju 1992 r. i został rozlokowany na obszarze Hercegowiny i południowo-wschodniej Bośni. Jego dowódca mianowano gen.-mjr. Radovana Grubača. Funkcję szefa sztabu pełnili gen.-mjr Vlado Spremo i Miladin Prstojević. Obszar operacyjny Korpusu rozciagał się od granicy z Czarnogórą i Chorwacja przez Prevlakę i Popovo Polje w kierunku Stolaca, Mostaru i we wschodniej Bośni do Goražde. Stan liczebny tej wielkiej jednostki operacyjnej wynosił około 20 tys. ludzi. Jednak w porównaniu z innymi siłami Serbów bośniackich liczba jednostek w jego składzie była początkowo stosunkowo niewielka: 1. i 8. brygady zmotoryzowane (ta ostatnia w Nevesinje), Mieszana Brygada Artylerii (główna kwatera Bileća), lekkie brygady piechoty - „Bilećka”, „Gatačka” (z miasta Gačko), „Konjicka”, „Fočanska” i „Trebinjska”. Brygada „Goraždanska” rozlokowana była w okolicach Goražde i z innymi jednostkami brała udział w walkach o to miasto bronione przez Muzułmanów. Podobnie jak w innych jednostkach VRS, także i w Korpusie Hercegowińskim znajdowały się, jako wzmocnienie ogniowe, jednostki artylerii (w tym wypadku bataliony). Niektóre z zestawień sił VRS podaja, że na przestrzeni 1993 r. w Korpusie były m.in. następujące siły: 8., 13., 145. i 473(?). brygady zmechanizowane oraz 5. Brygada Górska ${ }^{50}$.

Poza wspomnianymi jednostkami w poszczególnych korpusach powstawały w ramach VRS jednostki specjalnego przeznaczenia, jak Batalion Samochodowy przy Sztabie Generalnym VRS (Automobiljski Bataljon - Glauni Štab), Jednostka Zwiadu „Czarni” (Zavidačka Jedinica „Crni”), Jednostka Specjalna „Mando” z Ugljevika i Jednostka Specjalna „Osmaci” ${ }^{11}$. Przy każdym z korpusów funkcjonowały także odpowiednie komórki organizacyjne zajmujące się wywiadem i kontrwywiadem.

\section{Serbskie oddziały paramilitarne i ochotnicze oraz ich rola w konflikcie bośniackim}

Znaczącym uzupełnieniem dla VRS, z uwagi na swą liczebność i dynamikę działań, były różnorodne formacje paramilitarne (paravojni jedinice), które liczyły łącznie ponad 20 tys. członków ${ }^{52}$. Były one formowane na obszarach zamieszkałych przez ludność serbską w Chorwacji i w Bośni, ponadto ich szeregi zasiliły liczne grupy i ochotnicy przybyli z terenu Serbii i potem Federacyjnej Republiki Jugosławii $^{53}$. W tym względzie istotną rolę odgrywał Serbski Ruch Czetnicki

\footnotetext{
${ }^{50}$ Army of Republic of Srpska (Vojska...

${ }^{51}$ Republic of Srpska Army...

${ }^{52}$ Por. N. Thomas, K. Mikulan, dz. cyt., s. 13.

${ }_{53}$ Por. więcej S. Čekić, $d z$. cyt., s. 871 i n.
} 
(Srpski Četnicki Pokret) - Šešeljevci - kierowany przez znanego uprzednio dysydenta, a następnie polityka serbskiego o orientacji narodowej, Vojislava Šešelja. Zaplecze kadrowe stanowili też rezerwiści JNA, ludzie ze służb, a szczególnie ze służby bezpieczeństwa (SDB) oraz bardzo liczni kibice znanej drużyny Crvena Zvezda Belgrad i w niektórych przypadkach byli kryminaliści ${ }^{54}$. Jednostki paramilitarne zazwyczaj były umundurowane w komplety polowe, a ich żołnierze nosili czasami hełmy, częściej jednak berety i czapki (wojskowe lub wełniane, zdobione emblematami - serbskimi lub konkretnej jednostki ${ }^{55}$. Bardzo dobrze były zaopatrzone w broń strzelecka, a ich działania często wspomagały działa, moździerze i czołgi (T-34/85 lub T-55). Paravojnici znani byli z bitności i odwagi, ale też z okrucieństwa i przypadków zbrodni wojennych na ludności cywilnej. Wśród nich największy rozgłos zdobyła Serbska Gwardia Ochotnicza (Srpska Dobrovoljačka Garda, SDG) znana jako „Tygrysy Arkana” (Arkanovi Tigrovi) lub „Arkanowcy” (Arkanovci) dowodzona przez Željko Ražnatovicia, ps. „Arkan”.56.

${ }_{54}$ Por. M. Vasić, F. Švarm, Zadah zločina-srpske paravojne formacije 1990-2000, [w:] Ratovi u Jugoslaviji 1991-1995-zbornik saopštenja i diskusije za okrug stola Beograd 7-9 Novembar 2001, ur. R. Ratković, Beograd 2002, s. 243 i n.

${ }_{55}$ Por. Arkanovi Tigrovi u akcije, http://www.youtube.watch?v=04JoTsoCoqM\&feature=related.

${ }^{56}$ Swą działalność „Tygrysy” rozpoczęły w roku 1991 podczas wojny z Chorwatami w Slawonii i Baranji w okolicach miejscowości Erdut, w długotrwałych walkach o Vukovar i w innych miejscach (2. DEO Arkanovi Tigrovi u Krajine, http://youtube.com.watch?$\mathrm{v}=\mathrm{mCjihNsqkUUfeature=related).} \mathrm{Natomiast} \mathrm{w}$ wojnie w Bośni siły Ž. Ražnatovicia „Arkana” brały udział u boku VRS podczas walk i „czystek etnicznych” w Bijeljinie, Tesliciu, Fočy, Bratunacu, Zvorniku i w Prijedorze. Wspomniany dowódca (z zawodu cukiernik) znany był ze zwyczaju noszenia munduru wyjściowego wzorowanego na czasach Królestwa Jugosławii, krzyża znacznych rozmiarów na szyi, retoryki typowo nacjonalistycznej i „wielkoserbskiej” oraz z małżeństwa ze znaną z urody, popularną piosenkarką Svetlaną Veličković „Ceca”. Por. m.in. Željko Ražnatović Arkan, http://www.youtube.com/ watch?v=f4ByV1pkMc; Željko Ražnatović i Srpska Dobrovoljačka Garda u ratištu, http:// www.youtube.com/watch?v=H567ep7LFn08feature=related. W kilka lat po zakończeniu wojny, na przełomie 1999 i 2000 r. tego serbskiego watażkę, a wówczas biznesmena, zaczęło opuszczać powodzenie w interesach. Np. nie dopuszczono jego klubu piłkarskiego "Obilić" do rozgrywek europejskich. Także niektórzy wpływowi ludzie w Belgradzie, mający konflikt z prawem czy niechlubną wojenną przeszłość i perspektywę osądzenia przez ICTY, zaczęli się obawiać, czy „Arkan”, zagrożony ewentualną ekstradycja, nie zechce się swoją wiedzą o nich „podzielić” w ramach korzystnego dla siebie układu z sędziami z Hagi. $\mathrm{W}$ połowie stycznia $2000 \mathrm{r}$. został on w wyniku zamachu (łączonego także z jego domniemanymi związkami z mafia) śmiertelnie raniony. Na temat osoby i działalności „Arkana”, a także walk innych serbskich jednostek paramilitarnych, por. m.in. T. Olszański, dz. cyt., s. 66-70, 81-82; M. Vasić, F. Švarm, dz. cyt., s. 238 i n.; S. Čekić, $d z$. cyt., s. 874 i n.; V. Pandurević, Rat u Bosne i Hercgovine - paravojne formacije, Beograd 2004, s. 48 i n.; N. Thomas, K. Mikulan, dz. cyt., s. 13; S.L. Szczesio, Arkan i Ceca-serbski zbrodniarz 
Poza nią wymienić należy m.in. „Białe Orły” (Bjeli Orlovi) pod komendą Mirko Jovicia, oddziały „Dušana Silnego” i „Policji Specjalnej” z Krajiny dowodzonej przez „Kapetana/Kapitana Dragana” (serbski najemnik zamieszkały uprzednio w Australii, Dragan Vasiljković), „Czerwone Berety” (Crveni Beretka) dowodzone przez Franka „Frenki” Simatovicia, „Szare Wilki” (Sivi Vukovi) Slobodana Miljkovicia „Lugara” ${ }^{57}$, „Pantery-Mauzerowców” (Panteri-Mauzerovci) Ljubišy Savicia „Mauzera” i „Skorpiony” (Škorpioni) Slobodana Medicia ${ }^{58}$. Można także wspomnieć jeszcze o „Gwardii Serbskiej” (Srpska Garda) Vuka Draškovicia czy „Rojalistach” (Rojalisti) Mihajlo Mladjenovicia ${ }^{59}$.

Kolejne jednostki to m.in. „Serbskie Sokoły” (Srpske Jastrebovi) i „Gwardia Czarnogórska” (Crnagorska Garda) ${ }^{60}$. W roku 1992 „Białe Orły” działały np. pod Srebrenica, w walkach o Sarajewo, Gačko, Doboj, Bileceę, Višegrad, Modricę, Bosanską Krupę i Banja Lukę. Oddział „Dušana Silnego” brał udział w zdobyciu Zvornika. „Czetnicy” V. Šešelja walczyli w latach 1992-1993 pod Derventa, Nevesinje, Kupresem, Modrica, Tuzla, Maglajem i Kalinovikiem. Wraz z nimi w niektórych walkach brały udział „Tygrysy” (Sarajewo, Bosanski Šamac, Mostar, Brčko, Foča, Bratunac i in.). 110-osobowy oddział „Kapitana Dragana” walczył o Zvornik i Zavidovići, „,Szare Wilki” o Bosanski Šamac, a „Serbskie Sokoły” o zdobycie wspomnianego Zvornika oraz Fočy ${ }^{61}$. W październiku 1995 r., u schyłku wojny, ludzie „Arkana” dokonali „czystek etnicznych” na Muzułmanach pozostałych jeszcze w Banja Luce i w kilku innych miastach Bosanskiej Krajiny ${ }^{62}$.

Wsparcie i napływ ochotników zagranicznych do armii serbskiej w Bośni, głównie z krajów należących do cywilizacji prawosławnej, nastapił już w $1992 \mathrm{r}^{63}$

wojenny i gwiazda turbofolku, [w:] Księga Pamiatkowa XV Ogólnopolskiego Zjazdu Historyków-Studentów, t. II, Łódź 2008, s. 292 i n.; D. Wybranowski, Między niepodlegtościa..., s. 191.

${ }^{57} \mathrm{O}$ tej jednostce i losach jej dowódcy, por. Gray Wolves [Sivi Vukovi], http://www. fas.org/irp/world/para/sivi_vukovi.htm.

58 O działalności zbrojnej wspomnianych formacji paramilitarnych, por. m.in. M. Vasić, F. Švarm, dz. cyt., s. 238 i n.; S. Čekić, dz. cyt., s. 874 i n.; N. Thomas, K. Mikulan, dz. cyt., s. 13; O. Валецкий, dz. cyt., s. 167; Paravojne jedinice, http://www.plbih.info/cms/ Paravojne-jedinice,335.0.html?c-Hash=5f3ce914b6\&tx_t; Kapetan Dragan $i$ Vojislav Šešelj nišu se slagali, http://www.youtube. com/watch?v= q6vM865wliq; Garda Panteri... O problemie odpowiedzialności „Skorpionów” za udział w masakrze w Srebrenicy por. Počelo suđenje „S̆korpionima", http://www.b92.net/info/vesti/index.php?yyyy=2005\&mm=12dd=20dd= 20\&nav_category...; A. Skieterska, Serbskie Skorpiony skazane za mord w Srebrenicy, http://wyborcza.pl/ 2029020, 86675, 4049458.html_sms_code=.

${ }^{59}$ Por. S. Čekić, dz. cyt., s. 872.

60 Por. N. Thomas, K. Mikulan, dz. cyt., s. 13.

${ }^{61}$ Tamże.

${ }^{62}$ Por. M. Kuczyński, dz. cyt., s. 231.

${ }^{63} \mathrm{O}$ udziale ochotników z Rosji, Ukrainy, Rumunii i Grecji por. m.in. N. Thomas, K. Mikulan, dz. cyt., s. 13; A. Krzak, Charakterystyka działań militarnych w Bośni 
Ich ogólna liczba wynosiła ponad 4 tys. Ochotnicy przybyli z Rumunii walczyli w roku 1992 w okolicach Sarajewa. Znaczną grupę (około 700 ludzi) stanowili Rosjanie i Ukraińcy ${ }^{64}$. Z przybyszy rosyjskich sformowano kilka jednostek, z których najbardziej znaną były „Carskie Wilki” (Carskije Wotki) dowodzone przez Aleksandra Mucharewa. W jej składzie znalazła się kompania złożona z Kozaków. Ta ostatnia jednostka, pod komendą Aleksandra Zagrebowa, wsławiła się obroną wzgórza Zaglavak (zima 1993 r.). Inne rosyjsko-ukraińskie jednostki walczyły we wrześniu 1992 r. w okolicach Višegradu i o Sarajewo w latach 1992$1993^{65}$. Znana była także jednostka w sile 100-200 ludzi złożona z ochotników z Grecji - „Grecka Gwardia Ochotnicza” (Grčka Dobrovoljačka Garda, GDG). Walczyła ona m.in. w lipcu 1995 r. pod Srebrenicą w składzie Korpusu Drina ${ }^{66}$.

\section{Potencjał zbrojny Armii Republiki Serbskiej}

Jak podają N. Thomas i K. Mikulan, siły VRS tworzyło 77 „brygad” (często liczacych około 500 lub nieco więcej oficerów i żołnierzy niższych rangą, co odpowiada mniej więcej etatowi batalionu), w tym 2 brygady pancerne, 7 zmotoryzowanych, 22 piechoty lub nieoznaczone oraz 46 lekkich brygad piechoty ${ }^{67}$. Liczebność VRS, podobnie jak pozostałych stron konfliktu z lat 1992-1995, z uwagi na występującą fluktuację kadrową wynikającą z liczby zabitych, rannych, wziętych do niewoli, zaginionych, dokonywanych uzupełnień w poszczególnych jednostkach itp., była dosyć zmienna. Niemniej jednak, opracowania i zestawienia odnoszace się do pierwszych lat jej istnienia (1992-1993) podaja $\mathrm{z}$ reguły dane o około 80-85 tys. ludzi, łącznie z jednostkami paramilitarnymi i ochotniczymi ${ }^{68}$.

w latach 1992-1993, [w:] Bośnia i Hercegowina 15 lat..., s. 37; D. Omeragić, Uloga stranih dobrovoljaca $u$ agresije na BiH, http://jajceportal.com/modules.php?mame= News\&file=print\&sid=1231; Za ratne zločine nikad neće odgovarati Rusi, Grci, Rumuni..., http://www.bosnjacki-front.net/index.php?docid=410937081808; Русскйе добровольии y Босни/Russian volunteers in Bosnia, http://www.youtube.com/watch?v= wGsdYKiP4P88feature=related; Russian terrorists with Serbs attacking Bosnia, http://www. youtube.com/watch?v=rifaaEXA 6 ps\&feature= related.

${ }^{64}$ Por. N. Thomas, K. Mikulan, dz. cyt., s. 13.

65 Tamíe.

${ }^{66} \mathrm{O}$ problemie odpowiedzialności i obecności ochotników greckich podczas zdobycia Srebrenicy, por. m.in. I Grci sudjelovali u srebreničkom genocidu, http://www.bosnjacki-front.net/index.php?docid=120923160608.

67 Por. N. Thomas, K. Mikulan, dz. cyt., s. 12-13.

${ }_{68}$ Tamże, s. 12; M. Kuczyński, dz. cyt., s. 191; A. Krzak, dz. cyt., s. 35; Army of Republic of Srpska (Vojska... 
Dla wszystkich stron konfliktu bośniackiego kwestią zasadniczą była rywalizacja o maksymalny stopień pozyskiwania uzbrojenia i wyposażenia od armii federalnej czy z jej przejętych magazynów i koszar. Towarzyszyły temu niekiedy różnego rodzaju afery, nadużycia, korupcja, a nawet akty przemocy i przetrzymywania wysokich rangą oficerów armii jugosłowiańskiej jako zakładników ${ }^{69}$. Od początku Serbowie, z uwagi na wspomniane masowe przejmowanie sprzętu od JNA oraz przechodzenie na ich stronę całych jej jednostek zdobyli w tym względzie istotna przewagę nad swymi muzułmańskimi i chorwackimi przeciwnikami. Żołnierze VRS byli bardzo dobrze zaopatrzeni w broń strzelecka, a szczególnie w uzyskane od JNA z jej magazynów i koszar najliczniej używane karabinki szturmowe Zastava M70 (tj. AK-47), AK-74 i AKM, także starsze typy broni w rodzaju karabinów Mauser M48 ${ }^{70}$. Używali ponadto ręcznych karabinów maszynowych MG3 (odpowiednio zmodernizowana wersja niemieckiego MG-42), Zastava M72 (odpowiednik radzieckiego RPK), Zastava M84 (odpowiednik PK), ciężkich karabinów maszynowych Goriunowa, M07 (Browning MG50) i innych. W zasobach uzbrojenia VRS znalazły się również wielkokalibrowe karabiny maszynowe Zastava M02 i innych typów (odpowiednik radzieckiego DszK 12,7 i 14,5 mm), karabiny snajperskie Zastava M91 (odpowiednik radzieckiego SWD) i inne egzemplarze broni strzeleckiej. Podstawowym typem broni ręcznej używanym przez oficerów był pistolet Zastava M70. Dodatkowo siłę ognia pododdziałów i większych formacji wzmacniały ręczne granaty obronne i zaczepne, ręczne wyrzutnie pocisków i granatniki, a zwłaszcza RPG-7. Jak widać z powyższego zestawienia, znaczna część uzbrojenia strzeleckiego, podobnie jak i innego, pochodziła z produkcji krajowej (zwłaszcza słynne zakłady Crvena Zastava bądź potem Zastava) lub wytwarzano je na licencji radzieckiej.

Głowy żołnierzy chroniły w niektórych przypadkach hełmy przejęte również po JNA (początkowo nawet z czerwonymi gwiazdami, szybko zamalowywanymi potem narodowymi emblematami serbskimi). Jak jednak wspomniał O. Waleckij: „Stare hełmy po JNA mało kto nosił, a nowych po prostu nie było [...]. Głowy żołnierzy chroniły zatem furażerki, czapki i berety" ${ }^{\prime 1}$. Z czasem sukcesywnie wprowadzano, zwłaszcza w okresie powojennym, nowsze modele wykonywane

${ }^{69}$ Informacje w tym względzie przyniósł wspomniany wyżej proces gen. M. Perišicia. Niektóre sprawy związane z nielegalnym pozyskiwaniem broni przez Serbów i Muzułmanów oraz „incydentem z Dobrovoljačkej” z 3 maja 1992 r., gdy w Sarajewie ostrzelana została przez „ekstremistów muzułmańskich” wycofująca się kolumna JNA czy zatrzymaniem ówczesnego dowódcy 2. Okręgu Wojskowego (następcy R. Mladicia), gen. Milutina Kukanjaca i jego wymianą za prezydenta A. Izetbegovicia, przyniosły zeznania byłego ministra obrony RS, Dušana Kovačevicia. Wspomniany minister zeznawał w Hadze w lipcu 2010 r. jako świadek obrony. Por. Kako je VRS nabavljala oružje i municiju?, http:// www.sense-agency/comtribunal_(mksj)kako-je-vrs-nabavjlala-oruzje-i-municiju...

70 О. Валецкий, dz. cyt., s. 321-323.

71 Tamże, s. 313. 
z kevlaru, pokrywane materiałem maskującym, a na co dzień oficerowie i żołnierze niższych stopni poszczególnych jednostek i rodzajów broni nosili berety - czerwone, zielone, brązowe bądź czarne oraz czapki polowe, a także do munduru wyjściowego. Używane mundury wyjściowe, polowe i inne elementy wyposażenia, np. buty, plecaki, płaszcze, zestawy przeciwchemiczne, były początkowo „spadkiem” po armii federalnej. Dopiero z czasem zastapiła je własna produkcja lub import (legalny bądź nie). Spośród wszystkich sił zbrojnych biorących udział w konflikcie bośniackim wojska R. Mladicia były najlepiej uzbrojone i wyposażone, szczególnie w odziedziczoną po JNA broń ciężką. Jak pisał po wojnie w 1997 r. wspomniany gen.-płk M. Milovanović: „VRS była w latach 1992-1993 jedną z najsilniejszych armii na Bałkanach i w Europie" ${ }^{\text {"72. }}$.

Podstawowymi typami czołgów średnich używanymi przez Serbów bośniackich były T-55 i M-84 (jugosłowiańska wersja radzieckiego T-72). Poza tym, siły serbskie przejęły stosunkowo niewielką liczbę lekkich czołgów pływających PT-76. Bardzo dobrze w stosunku do innych armii konfliktu bośniackiego wygladało zaopatrzenie w bojowe wozy piechoty (bwp) BMP-1 i w jego jugosłowiańska odmianę - M-80, w gąsienicowe transportery opancerzone BTR-50 i M60 (ten ostatni wzorowany na amerykańskim M113 i austriackim Saurerze M4) i opancerzone samochody rozpoznawcze BOV M86 oraz BRDM-2 $2^{73}$. Ze starszych typów trafily nawet na front pamiętające II wojnę światową bądź lata powojenne czołgi średnie T-34/76 i T-34/85 $5^{74}$. Wojska serbskie przejęły także od JNA bardzo liczne pojazdy kołowe - samochody terenowe (zwłaszcza radziecki UAZ) i ciężarowe (np. TAM 110 i 150) ${ }^{75}$.

Siły Serbów w Bośni dysponowały również artyleria: zarówno lekką polową i przeciwlotniczą (23, 30, 37, 45 i $76 \mathrm{~mm})$, jak i armatami czy haubicami cięższego kalibru (85, 100, 105, 122, 130, 150 i $155 \mathrm{~mm}$ ) oraz moździerzami i granatnikami różnych typów (M-91 120 mm, M-42 82 mm, M-80 „Zolja” 64 mm, M-79 „Osa” $90 \mathrm{~mm}$ oraz „Malutka” i „Fagot”) ${ }^{76}$. Używane były podczas walk także działa bezodrzutowe 82 i $107 \mathrm{~mm}$. VRS przejęła również pewną liczbę samobieżnych haubic 2S1 „Goździk” i różnorodne samobieżne zestawy plot., w tym gąsienicowe ZSU-23-4 „Szyłka”, ZSU-57-2 i kołowe 9K33 „Osa”, M53/59 „Praga” (ten ostatni produkcji czechosłowackiej). Serbowie używali podczas walk także kilku typów wielolufowych wyrzutni rakietowych i zestawów rakiet (M-63

72 Tamize, s. 307.

73 Tamże, s. 315-320.

${ }^{74}$ Niektóre egzemplarze T-34 z armatami 76 mm (T-34/76) i T-34/85 były wycofane z linii i stanowiły muzealne eksponaty bądź pozostawały w zbiorach szkół i uczelni wojskowych. O liczbie i wybranych przypadkach używania tych czołgów w składzie poszczególnych korpusów VRS więcej zob. B. Dimitrijević, Tenkovi T-34 u ratovima 1991-1995, http://www.oklop.net23.net/t34_u-jugoslaviji/opis.html.

75 Por. Made in War, http://oklop2.tripod.com/made_in_war/war1.htm.

${ }^{76}$ O. Валецкий, $d z$. cyt., s. 314 . 
„Plamen”, M-77 „Oganj” i M-87 „Orkan”) ${ }^{77}$. Na wyposażeniu armii serbskiej w BiH znalazły się również ręczne wyrzutnie plot. produkcji radzieckiej lub na licencji - „Strijela” i „Igla”. Bardzo dobrze wyglądało także zaopatrzenie w różne rodzaje sprzętu saperskiego i kilka głównych typów min (TMM-1, TMA-1, TMA2, TMA-3, 4 i 5A $)^{78}$. Zachowany bardzo bogaty materiał filmowy i dokumentalny ukazuje żołnierzy serbskich w różnych sytuacjach, różnorodne typy uzbrojenia i wyposażenia VRS oraz jej siłę militarną ${ }^{79}$.

\section{Lotnictwo Armii Republiki Serbskiej}

Na Lotnictwo Wojenne/Bojowe Republiki Serbskiej (Ratno Vazduhoplovstvo RS, RV RS) i Obronę Przeciwlotniczą (Protiv-vazdušna Odbrana, PVO) dowodzone przez gen.-mjr. Živomira Ninkovicia składały się dywizjony przejęte po JNA, a wycofane z Chorwacji i Słowenii: 74. (były 474. Dywizjon JNA), ponadto 27. (były 237. JNA) i 28. (były 238. JNA) dywizjony bombowe stacjonujące na terenie bazy powietrznej Mahovljani koło Banja Luki ${ }^{80}$. Tworzyły one uprzednio 82. Brygadę Sił Powietrznych JNA. Za oficjalny dzień powstania RV i PVO VRS uważa się 27 maja 1992 r., tj. dzień pierwszych akcji bojowych ${ }^{81}$. $\mathrm{Na}$ stanie sił powietrznych VRS znalazły się również jednostki śmigłowców (przejęta została znaczna część 111. Brygady Powietrznej z obszaru Chorwacji, stacjonująca potem w bazie Zalužani koło Banja Luki). Kolejne jednostki wyposażone w śmigłowce bojowe, to 11. Pułk Śmigłowców oraz 711. i 780. dywizjony transportowe. W końcu 1992 r. posiadane przez Serbów jednostki lotnicze, tj. 711. i 780. dywizjony utworzyły 89. i 92. mieszane dywizjony śmigłowców

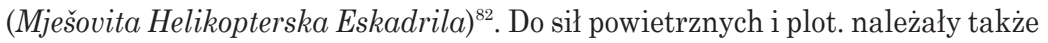
Służba Bezpieczeństwa Lotnictwa (Služba Bezbednosti Vazduhoplovstva), 474. Pułk Artylerii Lekkiej (Laki Artilerijski Puk), 155. Brygada Rakietowa (Raketna Brigada), 92. Mieszana Brygada Artylerii i bataliony obserwacji

77 Tamże, s. 305.

78 Tamże, s. 319.

${ }^{79}$ Por. m.in. Vojska Republike Srpske 2, http://www.yutube.com/watch?v=ytOhyYXCjJV; Vojska Republike Srpske (Bosnia Serb Army), http://www.youtube.com/ watch?v=98M4dBAJvBs.

${ }^{80}$ Por. N. Thomas, K. Mikulan, dz. cyt., s. 13.

${ }^{81}$ Por. reportaż Marka Nixona z jego wizyty w Banja Luce i w bazach lotniczych RS w styczniu 2003 r., Forged in War Dedicate, http://www.mycity-military.com/slika.php?slika=114563_54743_AFM\%20Januar... (tamże zarys kolejnych etapów dziejów RV i PVO RS, charakterystyka typów samolotów i śmigłowców bojowych, kadry dowódczej i nomenklatury nazewniczej oraz skrótów poszczególnych jednostek).

${ }^{82}$ N. Thomas, K. Mikulan, dz. cyt., s. 13. 
[celów powietrznych], wykrywania i naprowadzania (bataljon Vazdušni Osmatranje, Javljanje i Navodjenje, bVOJIN), wyposażone w radary i inny sprzęt ${ }^{83}$. Poszczególne jednostki lotnicze były rozlokowane na lotniskach w Bratunacu, Prijedorze i Zalužani.

Podstawowym sprzętem lotniczym RV RS były m.in. myśliwce MiG-21, myśliwsko-szturmowe J-21 „Jastreb”, J-22 „Orao” oraz samoloty szkolno-bojowe Soko G-3 „Galeb” i G-4 „Super-Galeb” ${ }^{4}$. Były to konstrukcje na licencji radzieckiej lub krajowe, projektowane w koprodukcji (np. z Rumunia) i na podzespołach zachodnich. Najczęściej spotykanymi typami śmigłowców bojowych były Mi-8 i francuski SA 342L „Gazelle”. Znaczący w stosunku do przeciwników potencjał lotniczy Serbów został zniwelowany przez kategoryczny zakaz lotów bojowych w wyniku nacisków Zachodu ${ }^{85}$. NATO dysponowało miażdżąca przewaga liczebną i techniczną w powietrzu, aczkolwiek zakaz lotów był przez Serbów notorycznie łamany. Poza tym, na przestrzeni od kwietnia 1992 do końca stycznia 1993 r. licznych nalotów i bombardowań miały dokonać na cele na obszarze $\mathrm{BiH}$ samoloty lotnictwa federalnego ${ }^{86}$. W wojnie z lat 1992-1995 samoloty serbskie dokonywały nalotów (np. w walkach o Bihać w 1994 r. z lotniska Udbina w zdobytej chorwackiej Krajinie), cztery z nich, typu „Super-Galeb” w lutym 1994 r. zostały zestrzelone przez myśliwce NATO ${ }^{87}$.

\section{VRS i jej przeciwnicy podczas wojny}

Z uwagi na to, iż problem serbskich działań militarnych lat 1992-1995 stanowi obszerne, oddzielne zagadnienie, które znacznie przekracza rozmiary niniejszej publikacji, autor jedynie zasygnalizował niektóre wątki z tym związane. Pominięte zostały też ze względu na wymogi redakcyjne znaczące operacje armii Serbów bośniackich, np. „Koridor”, „Breza 92”, „Sadejstvo 93”. Pierwsze miesiące konfliktu ukazały bardzo dobrze przewagę sił serbskich, które dzięki

${ }^{83}$ Por. Forged in War...

${ }^{84}$ Por. Ratno Vazduhoplovstvo i Protiv-vazdusna Odbrana RS.wmv, http://www. youtube.com/watch?v=JUEL 7sufIJM.

${ }^{85}$ Zakaz lotów dla serbskich samolotów został wydany na mocy rezolucji nr 816 Rady Bezpieczeństwa ONZ z dnia 31 marca 1993 r. Por. Resolution 816 (1993), http:// www.nato.int/ifor/un/u930331a.htm.

${ }^{86}$ Por. szczegółowo na ten temat S. Čekić, $d z$. cyt., s. 785 i n.

${ }^{87}$ M. Kuczyński, dz. cyt., s. 210 i n. Szerzej na temat operacji lotnictwa Sojuszu Północnoatlantyckiego w Bośni (,Sky Monitor”, „Deny Flight”, „Deliberate Force”), por. m. in. W. Leśnikowski, Lotnictwo NATO na Batkanach, „Przegląd Sił Powietrznych” 2008, $\mathrm{nr}$ 1; S.L. Szczesio, Rola NATO w konflikcie bośniackim (1992-1995), [w:] Konflikty i spory międzynarodowe, t. 2, pod red. R. Łosia i J. Reginii-Zacharskiego, Łódź 2010, s. 307-313. 
uzyskiwanemu od JNA uzbrojeniu i wyposażeniu dość szybko zajmowały coraz to nowe miasta i obszary $\mathrm{BiH}$ (w szczytowym okresie $70-72 \%$ terytorium) ${ }^{88}$. W toku wojny żołnierze VRS wzięli udział $\mathrm{w}$ walkach $\mathrm{z}$ armią bośniacką o Podrinje i obszar Wschodniej Bośni, Posawinę (zwłaszcza Brčko, Derventa, Bosanski Brod), podczas oblężenia Sarajewa i o wzgórze Igman, na terenie Hercegowiny w zmaganiach o Mostar, Livno i Grahovo, a także o Bosanską Krajinę, w tym Prijedor, Sanski Most, Mrkonjić Grad i Bihać ${ }^{89}$. Oprócz walk z armią rządowa, siły serbskie ścierały się niejednokrotnie z Chorwatami, szczególnie we wspomnianej Hercegowinie, Bośni Środkowej (m.in. Jajce, Kupres, Zvornik) i na Posawinie. Mimo zadawnionego antagonizmu serbsko-chorwackiego, VRS epizodycznie wspierała artylerią i sprzętem pancernym Chorwatów i Chorwacką Radę Obrony (HVO) podczas konfliktu bośniacko-chorwackiego z lat 1992-1993 ${ }^{90}$. Serbowie nieraz także mieli okazję do walki z islamskimi mudżahedinami walczącymi po stronie rządu sarajewskiego ${ }^{91}$. W roku 1995 VRS stoczyła walki o zdobycie Srebrenicy (w której okolicach żołnierze serbscy dokonali masakr kilku tysięcy Muzułmanów) i Žepy oraz pod Tuzlą, w masywie Majevicy, Ozrenu i o Brčko. Nadal trwał też serbski ostrzał oblężonego od lat Sarajewa i podejmowane były próby zdobycia Goražde i Bihacia. Zmasowane naloty NATO w toku operacji „Deliberate Force” zadały znaczne straty infrastrukturze militarnej i logistycznej wojsk serbskich.

${ }^{88}$ Por. m.in. B. Zieliński, Krwawe puzzle, „Wprost” 1994, nr 7, s. 52-53 (tamże mapa spornych obszarów i zasięgu terytoriów w posiadaniu walczących stron).

$89 \mathrm{Z}$ uwagi na bardzo bogatą literaturę problemu, por. m.in. M.J. Calic, Der Krieg in Bosnien und Herzegovina: Ursachen, Konfliktstrukturen, internationale Lösungversuche, Frankfurt am Main 1995; I. Banac, Cijena Bosna: članci, izjave i javni nastupi 1992-1995, Sarajevo 1995; E. O'Ballance, Civil War in Bosnia 1992-1994, London-New York 1995; M. Kuczyński, dz. cyt., s. 186 i n.; О. Валецкий, dz. cyt., s. 209 i n.; A. Krzak, dz. cyt., s. 40 i n.; D. Wybranowski, Między niepodległościq..., s. 207 i n.

${ }^{90} \mathrm{O}$ walkach chorwacko-muzułmańskich i przypadkach udostępniania za naprawdę znaczne kwoty przez Serbów sprzętu Chorwatom, por. m.in.: E. O’Ballance, dz. cyt., s. 64 i n.; M. Kuczyński, dz. cyt., s. 195 i n.; Ch. Shrader, The Muslim-Croat Civil War in Central Bosnia. A Military History, 1992-1994, College Stadion 2003, s. 167-169; O. Валецкий, $d z$. cyt., s. 245 i n.; W. Walkiewicz, dz. cyt., s. 262 i n.; A. Krzak, dz. cyt., s. 48; D. Wybranowski, Unia Europejska a zatarg muzułmańsko-chorwacki o Mostar w latach 90. XX wieku. U poczatków Wspólnej Polityki Zagranicznej i Bezpieczeństwa UE wobec obszaru byłej Jugosławii, [w:] Międzynarodowe role Unii Europejskiej - wybrane aspekty, red. A. Staszczyk, T. Czapiewski, Szczecin 2011, s. 176 i n.; tenże, Między niepodległościq..., s. 212 i n.; Petrović: Vojska RS iznajamljivala oružje hrvatskim snagama, http://www.islambosna.ba/vijesti/vijesti-svijet/17391-petrovi-vojska-rs-iznajmljivala-oruje-hrvatskim-snagama.

${ }_{91}$ Por. m.in. М. Миловановић, Ислалски терористи у Босни и Херцеговини, Банја Лука 2001, s. 7; M. Toholj, Sveti ratnici i rat u Bosne i Hercegovini, Beograd 2001, s. 76 i n.; D. Wybranowski, Poczatki i pierwsze lata działalności Armii Republiki Bośni i Hercegowiny, [w:] Bośnia i Hercegowina 15 lat..., s. 67-68. 
Przygotowały też grunt pod wielką ofensywę chorwacko-muzułmańską w Bosanskiej Krajinie i na Posawinie, która odebrała Serbom znaczną część zdobyczy z lat 1992-1993, a także zagroziła samej Banja Luce. To w dużej mierze naciski Zachodu i interwencja NATO odebrały w $1995 \mathrm{r}$. praktycznie pewne zwycięstwo militarne armii gen. R. Mladicia i złamały jej długotrwała militarna przewagę.

Natomiast jak wyglądał stan sił zbrojnych Serbów bośniackich i ich przeciwników na początku wojny prezentuje poniższe zestawienie (tab. 1):

Tabela 1. Uzbrojenie stron walczących w Bośni 31 grudnia 1992 r.

\begin{tabular}{|l|c|c|c|c|}
\hline \multicolumn{1}{|c|}{$\begin{array}{c}\text { Kategorie } \\
\text { sprzętu }\end{array}$} & Typ/kaliber & Serbowie & Chorwaci & Armia BiH \\
\hline Czołgi & M-84, T-54 i T-55 & ok. 350 & ok. 105 & ok. 15 \\
\hline $\begin{array}{c}\text { Bwp i transpor- } \\
\text { tery opance- } \\
\text { rzone }\end{array}$ & M-80 & 200 & 30 & 10 \\
\hline Działa & kaliber od 76 do $203 \mathrm{~mm}$ & 1000 & 170 & 20 \\
\hline $\begin{array}{l}\text { Wielolufowe } \\
\text { wyrzutnie rakiet }\end{array}$ & 128 i $262 \mathrm{~mm}$ & 60 & 15 & 5 \\
\hline $\begin{array}{l}\text { Działa } \\
\text { bezodrzutowe }\end{array}$ & $82 \mathrm{i} 105 \mathrm{~mm}$ & 800 & 250 & 100 \\
\hline Moździerze & 82 i $120 \mathrm{~mm}$ & 1200 & 300 & 200 \\
\hline $\begin{array}{l}\text { Samoloty bojowe } \\
\text { MiG-21, „Jastreb”, „Orao”, }\end{array}$ & 45 & 1 MiG-21 & - \\
\hline $\begin{array}{l}\text { Śmigłowce } \\
\text { uzbrojone }\end{array}$ & SA 342 L „Gazelle” & 10 & $\begin{array}{c}3 \text { Bell- } \\
\text {-Ranger }\end{array}$ & - \\
\hline
\end{tabular}

Źródło: M. Kuczyński, Krwawiaca Europa. Konflikty zbrojne i punkty zapalne w latach 1990-2000, Warszawa 2001, s. 198.

Można dodać tytułem uzupełnienia, że VRS była niekiedy wspierana przez siły Serbów chorwackich, którzy stworzyli na obszarach przez siebie kontrolowanych Armię Serbskiej Republiki Krajiny (Vojska Republike Srpske Krajine, VRSK) lub też to ona udzielała im w niektórych przypadkach, np. podczas walk na Posawinie lub w Bosanskiej Krajinie, czynnego poparcia w walkach przeciw armii chorwackiej ${ }^{92}$.

${ }_{92}$ Podobnie jak w przypadku terenu BiH i powstania VRS, Serbowie chorwaccy utworzyli VRSK na bazie Obrony Terytorialnej i części jednostek JNA rozlokowanych w Chorwacji. Siły VRSK dowodzone przez gen. Milana Čeleketicia były złożone z 6 kor- 
Liczba 80 tys. żołnierzy VRS, jeśli wierzyć zestawieniu sporządzonemu przez Międzynarodowy Instytut Studiów Strategicznych w Londynie, a opublikowanemu przez jugosłowiańską „Borbę” (por. niżej) została utrzymana jeszcze w 1994 r., po ponad dwóch latach wyczerpujących niekiedy walk. Potencjał ludzki armii Serbów bośniackich i sprzymierzonych z nimi chorwackich w porównaniu z siłami zbrojnymi pozostałych stron konfliktu przedstawiał się wtedy następująco:

Tabela 2. Potencjał wojskowy na terytorium BiH, Chorwacji

i Federacyjnej Republiki Jugosławii w 1994 r.

\begin{tabular}{|c|c|c|c|c|c|}
\hline Strona konfliktu & $\begin{array}{c}\text { Liczba } \\
\text { żołnierzy } \\
\text { (w tys.) }\end{array}$ & Czołgi & Artyleria & Samoloty & Śmigłowce \\
\hline Muzułmanie & 110 & 40 & 400 & & \\
\hline Chorwaci bośniaccy & 50 & 75 & 200 & & \\
\hline Armia Republiki Chorwacji & 110 & 170 & 90 & 20 & 10 \\
\hline Siły VRS & 80 & 330 & 800 & 40 & 30 \\
\hline $\begin{array}{l}\text { Armia Serbskiej Republiki } \\
\text { Krajiny }\end{array}$ & 50 & 240 & 50 & 12 & 6 \\
\hline $\begin{array}{l}\text { Federacyjna Republika } \\
\text { Jugosławii }\end{array}$ & 125 & 600 & 600 & 200 & 100 \\
\hline
\end{tabular}

Źródło: J. Ninković, Etnička strana ratova u Jugoslaviji 1991-1995, Beograd 2002, s. 159 .

pusów (21. Kordunski, 39. Banijski, 18. Zachodnioslawoński, 11. Wschodnioslawoński, 15. Licki i 7. Dalmatyński). Korpusy tworzyło łącznie 26 brygad i 5 wydzielonych pułków. Jednak nomenklatura operacyjna, podobnie jak i w przypadku bośniackim, nie odpowiadała rzeczywistości. Przykładowo, z uwagi na stan liczebny, każdy korpus odpowiadał etatowi brygady, a brygada batalionowi. Każdy korpus był złożony z 3-6 brygad oraz korpuśnych mieszanych jednostek, tj. pułków lub dywizjonów artylerii pułkowej. W roku 1995 na obszarze Korduna został sformowany kolejny, specjalny siódmy korpus. Właściwie był on szóstym, bo wspomniany wyżej 18. Korpus nie osiagnął nigdy wymaganego stanu pod względem liczby żołnierzy. W tymże roku siły serbskie w Chorwacji były wyposażone w 240-330 czołgów (z czego 30 to M-84), 160 transporterów opancerzonych (i być może także bwp), 560 dział różnego typu, 230 dział i zestawów plot., 22 samoloty bojowe i 18 śmigłowców. W praktyce pod bronia pozostawało 38 tys. ludzi, poza tym rezerwa liczyła 14,5 tys., a milicja ok. 4,1 tys. ludzi. Więcej na temat okoliczności powstawania i szczegółowego składu VRSK, jej struktury, składu operacyjnego poszczególnych korpusów i nazwisk dowódców oraz walk na obszarze Krajiny i Zachodniej Bośni, por. M. Sekulić, Knin je pao u Beograda, Bad Vilbel 2001, s. 31-35 i n.; О. Валецкий, dz. cyt., s. 201, 254 i n., 278, 291 i n.; Vojska Republike Srpske Krajine, http:/stefl24.tripod.com/krajina.htm; N. Barić, Položaj hrvatskog stanovništva na Banovini za vrijeme Republike Srpske Krajini (1991.1995.), http://www.cpi.hr/ download/l inks/hr/7298.pdf. 
W roku 1995 przewaga serbska zaczęła w sposób widoczny maleć, nie tylko z uwagi na straty w ludziach, ale także na skutek zbyt dużego rozciagnięcia obszaru operacyjnego, linii zaopatrzenia i długości frontów. Siły Serbów bośniackich miały wynosić wówczas 80 tys. żołnierzy (zapewne osiagnięto maksimum mobilizacyjne, przy czym bardzo prawdopodobne jest zasilenie przez żołnierzy jednostek VSRK po ich rozbiciu przez Chorwatów podczas opanowywania Krajiny bądź wlicza się w to rezerwistów). Dla porównania w powyższym zestawieniu Bośniacy (ARBiH) i Chorwaci (HVO) mieli łącznie 293 tys. wojska - tu także widać bardzo znaczny postęp w liczbie sił muzułmańskich (ponad 200 tys., co jednak dla tego okresu jest chyba zbyt wysokim wskaźnikiem), a szczególnie w przypadku jednostek chorwackich. Natomiast Serbowie prawdopodobnie nadal utrzymywali przewagę w sprzęcie - 500 czołgów, 280 transporterów opancerzonych, 1800 dział, 42 samoloty (te ostatnie, z uwagi na przewagę NATO w powietrzu i zakaz lotów, poza bardzo nielicznymi przypadkami, nie były używane). Ich przeciwnicy rzekomo posiadali łącznie tylko 100 czołgów, 70 transporterów i 760 dział ${ }^{93}$. Jest to bardziej prawdopodobne tylko w odniesieniu do Muzułmanów lub do samych jednostek HVO, aniżeli łącznego potencjału, gdyż do schyłku wojny liczba wozów bojowych i dział, w wyniku dostaw i łamania embarga, mogła dość znacząco wzrosnąć.

Pewnym wspomożeniem dla VRS mogły być do pierwszej połowy $1995 \mathrm{r}$. siły VRSK (formalnie 75 tys. ludzi, 250 czołgów, 140 bwp i transporterów opancerzonych oraz 600 dział) ${ }^{94}$. Jednak wielkie ofensywy Chorwatów („Bljesak” i „Oluja”) doprowadziły do zajęcia przez armię chorwacką w maju i sierpniu 1995 r. absolutnej większości obszaru tego państewka serbskiego ${ }^{95}$. Pomoc z tej strony dla Serbów bośniackich stała się więc dosyć iluzoryczna. Niespodziewana klęska, którą przyniosły zmasowane ofensywy bośniacko-chorwackie w sierpniu-wrześniu 1995 r. na pewno osłabiła VRS i zmusiła ją do oddania tych miast i regionów, które wydawały się już ostatecznie zdobyte. Prawdziwy „pogrom” i okrojenie armii Serbów bośniackich do wręcz symbolicznych rozmiarów na stopie pokojowej, przyniosły dopiero lata powojenne i polityka oraz naciski Zachodu. Jest to jednak temat na oddzielne studium.

93 J. Ninković, dz. cyt., s. 159.

94 Tamíe.

${ }_{95} \mathrm{Na}$ temat wspomnianych operacji sił chorwackich na obszarze serbskiej Krajiny w 1995 r. i jej skutków szerzej por. m.in. M. Kuczyński, dz. cyt., s. 217 i n.; J. Paszkiewicz, Exodus Serbów $z$ Chorwacji $i$ główne problemy zwiazane $z$ ich powrotem (1991-2002), [w:] Europa - Polska - Migracja, red. S. Wojciechowski, R. Fiedler, Poznań 2003; D. Pavličević, dz. cyt., s. 542 i n.; D. Marijan, dz. cyt., s. 50 i n.; О. Валецкий, dz. cyt., s. 383 i n. 